\title{
Immigration and student achievement: Evidence from Switzerland
}

\author{
Muriel Meunier*
}

Cahier : $N^{\circ} H E S-S O / H E G-G E / C--10 / 3 / 1-C H$

2010

* Geneva School of Business Administration, Bat. F, rte de Drize 7, 1227 Carouge,

Switzerland. E-mail: muriel.meunier@hesge.ch 


\title{
Immigration and student achievement: Evidence from Switzerland
}

\author{
Muriel Meunier
}

Cahier de recherche

Avril 2010

\section{Summary}

This paper investigates empirically whether immigrant students in Switzerland perform poorly compared to their native counterparts and provides some explanations. Using a national sample of the 2000 PISA (Programme for International Student Assessment) database, we first analyze the impact of immigrant status on pupils' achievement. We find a negative and significant impact of immigrant status on test scores in reading, mathematics and science literacy, even after controlling for a set of characteristics. We then decompose the observed reading score gap between Swiss and immigrant students to identify whether gaps in endowments explain test score differences along the distribution. Lower endowments explain most of the achievement gap in reading between Swiss and second-generation immigrants. However, lower returns explain around one quarter of the achievement gap between Swiss and first-generation immigrants for the weakest pupils.

\section{Keywords}

Educational production; Achievement gap; Immigration; PISA

\section{Acknowledgements}

The author thanks Ulrich Blum, Jennifer Hunt and Oscar Marcenaro for helpful comments on earlier versions. She gratefully acknowledges financial support granted by the Swiss Leading House Economics of Education (Federal Office for Professional Education and Technology). Part of this paper was written when the author was visiting the Institute of Education (University of London, UK) and Princeton University. The hospitality of these institutions is also gratefully acknowledged. The usual disclaimers apply. 


\section{Introduction}

Over the last three decades, the share of immigrants in the OECD population almost doubled from just over 4.5\% in 1975 to $8.3 \%$ in 2005 (Martin, 2008). Despite marked differences across countries, concerns about immigration have increased in most of them. As a matter of fact, this phenomenon not only affects the labour market but also the educational system. Recent international student assessments show that the observed achievement gaps between immigrant students and their native counterparts are important and vary widely in international comparison (OECD, 2006).

This paper examines the educational performance of first and second-generation immigrant students in Switzerland. We specifically focus on reading, mathematics and science literacy in the last year of compulsory school (grade 9). Switzerland presents a particularly interesting profile to examine questions relative to immigrants. First, the country has one of the highest shares of the foreign-born population $(22.6 \%$ in 2000$)$ in the OECD while in countries such as France or Germany, the proportion of immigrants in the population is only about above $10 \%$ (OECD, 2008). Second, the proportion of young people from immigrant families has been increasing for twenty years, from $14 \%$ in 1980 to $21 \%$ in 2000 (FSO, 2002). Finally, while Switzerland has one of the highest gross domestic product per capita and also one of the highest cumulative expenditure on educational institutions per student among OECD countries, the PISA 2000 international ranking has pointed out unexpectedly poor results. The country is ranked $17^{\text {th }}$ out of 27 participating OECD countries in reading, $18^{\text {th }}$ in sciences and $7^{\text {th }}$ in mathematics (OECD, 2002).

This paper addresses two main empirical questions. First, we aim to assess whether immigrant's students perform significantly better or worse than their Swiss counterparts, even after controlling for various characteristics. We use the national option to the 2000 PISA international database because reading literacy is the key domain. An educational production function (EPF) framework is used to evaluate the impact of migrant status on test scores.

The second key issue addressed in this paper concerns the hypothesis according to which lower performance of immigrant students are generally attributed to lower endowments. To address this issue, we focus our attention on the achievement gap in reading literacy between Swiss and immigrant students along the whole distribution of scores. One reason for doing so is that the achievement gap between Swiss and immigrants is decreasing along the distribution. We implement the Juhn, Murphy and Pierce (1993) decomposition in order to analyze between-group differences along the whole distribution.

This study expands on the existing empirical literature from at least three points of view. First, this work provides empirical evidence about immigrant students for Switzerland. Due to the important share of immigrants in Switzerland, we are able to investigate first and secondgeneration separately. Second, we provide results based on the national option to the PISA international sample. The advantage of using this national sample is that it contains only students in their last year of compulsory school (grade 9) while the international sample generally used in cross national comparisons is an age-based sample (15-year-old students). This is important as the international sample for Switzerland lumps together students from different grades because of the highly decentralized structure of the Swiss educational system. Third, we provide results not only focused at the mean (by estimating an EPF by OLS) but also along the whole distribution (by implementing the Juhn, Murphy and Pierce decomposition).

Two results of our analysis in particular stand out. First, we find a negative and significant impact of immigrant status on test scores in reading, mathematics and science literacy, even after controlling for individual characteristics, family background and schools characteristics. The negative impact of immigrant status is more important for first-generation immigrants 
than for second-generation immigrants. On average, speaking a language at home different from the language of the test is not more penalizing for immigrant students than for the Swiss. The Juhn, Murphy and Pierce decomposition also reveals interesting patterns. Lower endowments explain on average most of the achievement gap in reading between Swiss and second or first-generation immigrants. While there is no difference for second-generation immigrants between the weakest and the better half of students, this is not the case for firstgeneration immigrants. For the latter, lower returns explain around one quarter of the achievement gap for the weakest pupils.

A number of previous studies address the question of the impact of migrant status on test scores or on the gap in test scores between natives and immigrants. Some of them focus on the specific language hypothesis according to which immigrant student perform worse because they don't speak the language of the test. Using PISA 2000 in nine countries, Entorf and Minoiu (2005) argue that migrant students improve significantly their reading proficiency scores when the language spoken at home is the national language as opposed to some foreign language. Using three international databases (TIMSS 1995 and 1999, PIRLS 2001 and PISA 2003) in ten OECD countries, Schnepf (2007) finds that language skills seem to explain immigrants' disadvantage in English-speaking countries whilst socioeconomic background and school segregation are further important determinants of immigrants' gap in Continental European countries. In a cross national context with eight high-immigration countries including Switzerland, Schnepf (2008) argues that language skills impact more on educational achievement at lower percentiles than at the top of the achievement distribution. Other studies provide empirical evidence for specific countries. Using an extended version of PISA 2000 data for Germany, Ammermueller (2007) finds that German students perform better than immigrants because they have a more favourable family background, particularly in the lower part of the test score distribution. However, the author does not distinguish between first and second-generation immigrants. Using a specific PISA 2000 sample for Copenhagen (Denmark), Rangvid (2007) finds that in schools attended by immigrant students, the culture of achievement appears less well developed. To date, there is little empirical evidence about the education of immigrants in Switzerland. One reason is the lack of data mainly due to the decentralized organization of the Swiss educational system. However, Bauer and Riphahn (2007) investigate the patterns of intergenerational education transmission for natives and second-generation immigrants with the 2000 Swiss Census. The authors argue that children disadvantaged by parental background have only limited opportunities to catch up educationally.

The remainder of the paper is organized into two parts. Section 1 focuses on the impact of immigrant status on reading, mathematics and science literacy. We start by presenting briefly the data and some specificities of the Swiss educational system. We then present the empirical strategy, some descriptive statistics and the results. Section 2 investigates the achievement gap between Swiss and immigrants in reading literacy. We first analysis graphically the achievement gap and then introduces the Juhn, Murphy and Pierce (JMP) methodology. We then present the results. Finally, the last section concludes with a discussion of the findings.

\section{The impact of immigrant status on reading, mathematics and science literacy}

The primary goal of this research is to quantify the impact of immigrant status on reading, mathematics and science literacy in Switzerland. This country presents a particularly interesting profile to examine questions relative to immigrants for the following reasons. First, Switzerland has the highest population share of foreigners in the OECD (OECD, 2003). In 2000 , about $20 \%$ of its resident population did not hold a Swiss passport, which is much more than in many traditional countries of immigration. Second, the proportion of young people 
from immigrant families has been increasing for twenty years, from $14 \%$ in 1980 to $21 \%$ in 2000 (FSO, 2002). Consequently the effects on compulsory schooling are important and the Swiss education system must find a way to meet the challenge represented by immigrant pupils (OFS and CDIP, 2005). Also Switzerland is thus a useful benchmark for other countries where immigration is an important issue.

\section{The Swiss education system}

Switzerland is a federal state composed of 26 Cantons. Three official languages are traditionally spoken in different regions of the country ${ }^{1}$ : German, spoken by around $60 \%$ of the population, mainly in the 19 officially German-speaking Cantons; French, spoken by around $20 \%$ of the population, mainly in the 6 officially French-speaking Cantons; Italian, spoken by around $7 \%$ of the population, mainly in the only one officially Italian-speaking Canton. ${ }^{2}$ The main responsibility for education lies with the 26 Cantons that compose the country (these Cantons enjoy even more autonomy than U.S. States or German Länder). This decentralized structure implies that each Canton deals with its region-specific school traditions and the cultural differences in a multilingual country. As a results there is not one but rather 26 different educational systems.

An important implication of this relates to the organization of compulsory schooling. The compulsory schooling system is composed of the primary and lower secondary levels. Each pupil begins at the age of 6 and continues school for nine years. In most Cantons, the primary level lasts 6 years (grades 1 to 6 ) and the lower secondary level 3 years (grades 7 to 9) but in a few of them, the primary level lasts 4 or 5 years and the lower secondary level 5 or 4 years ${ }^{3}$. The lower secondary level provides basic general education and preparation for basic vocational education and training or for transfer to schools providing a general education at the upper secondary level. At the end of compulsory schooling, more than $50 \%$ of young people chose a practical vocational training, which lasts up to three or four years.

Another implication relates to the data available for analyzing the Swiss education system. In fact, each Canton is responsible for its own collection of data. As a result there is no systematic evaluation at the country level at the end of compulsory school (such as central exit examination like the Brevet des collèges in France or the General Certificate of Secondary Education (GCSE) in the United Kingdom) and most of the data available comes from data at the Cantonal level aggregated at the national level by the Federal Statistical Office (FSO). No database offers the possibility of analyzing the specific case of the Swiss education system at the national level. In order to fill out this gap, Switzerland has participated in international assessment such as TIMSS (Trends in International Mathematics and Science Study, 1995) or PISA (Programme for International Student Assessment, 2000, 2003 and 2006). The PISA 2000 international ranking has produced unexpectedly bad results for Switzerland and triggered a need in the country to investigate its education system.

\section{Data}

This study uses individual-level data from the Programme for International Student Assessment (PISA), administered in 2000 by the Organization for Economic Cooperation and

\footnotetext{
1 Romansh is also an official language but spoken locally by a small minority.

2 The German-speaking Cantons are Aargau, Appenzell outer Rhodes, Appenzell inter Rhodes, Bern, Baselcounty, Basel-city, Glarus, Grisons, Lucerne, Nidwalden, Obwalden, St Gallen, Schaffhausen, Solothurn, Schwyz, Thurgau, Uri, Zug, Zurich; the French-speaking Cantons are Fribourg, Geneva, Jura, Neuchatel, Valais, Vaud; the Italian-speaking Canton is Ticino.

3 The exceptions are: Aargau, Basel-county, Neuchatel, Ticino ( 5 years +4 years) and Basel-city and Vaud (4 years +5 years $)$.
} 
Development (OECD, 2002). PISA 2000 surveyed reading, mathematical and scientific literacy, with a primary focus on reading. The literacy scales in reading, mathematics and sciences are scaled and centered so as to have an average score of 500 points and a standard deviation of 100. Literacy in each domain focused on the student's ability to apply their knowledge and experience to real life situations. In addition to the assessments, PISA 2000 included a student questionnaire (designed to collect information about the student's family and home environment) and a school questionnaire (covering, in particular, issues such as the demographics of the school, school staffing and the school environment). The sampling design is a two-stage stratified sample: a selection of a sample of schools and then a random sample of pupils within each school.

PISA 2000 is an excellent data source with which to analyze the performance of immigrant students because the reading literacy is the key domain being tested. This means that students spent more time for the reading assessment (approximately 270 minutes of testing time) than for mathematics and science assessments (approximately 60 minutes of testing time each). This is particularly important for immigrant's students as language skills and reading literacy skills are strongly related.

In addition, Switzerland included a national option to the PISA international database. While the PISA international database is an age-based sample (15-year-old students), the national option surveys grade 9 students (the last year of compulsory school) and over-sample them in some parts of the country. ${ }^{4}$ We use the PISA national database because test scores for pupils in the same grade are more relevant to study the type of questions addressed in this paper. Moreover, the national sample size is bigger (7997 students) than the international dataset (6100 students). We restrict the original national sample to the students who did answer the questions relative to their immigration status and/or to the students attending schools in which at least 8 students have been sampled for the PISA survey. In total, 207 students have been excluded (i.e. $2.6 \%$ of the original national sample). Therefore, the reference sample used for the empirical part of the paper consists of 7790 students in 229 schools.

Finally, we use two different samples for mathematics literacy (4328 students) and science literacy (4334 students). These samples are smaller because while each student has been assessed in the reading domain, only a subset of students was assessed in mathematics and/or science.

\section{Definition of immigrant status}

The background questionnaire of the PISA survey does not ask any question about citizenship. However, one set of questions asks about the countries of birth of the pupil, his mother and his father separately (OECD, 2002). Unlike most citizenships, the Swiss one is acquired through the "right of blood" (Jus sanguinis), namely, it is not determined by the place of birth (Jus soli).

Table 1 presents the definition of immigrant status. Pupils have been dividing into three groups: Swiss or native (child with at least one parent born in Switzerland, no matter where the pupil was born), second-generation immigrant (child born in Switzerland with both parents born abroad) and first-generation immigrant (child born abroad with both parents born

\footnotetext{
4 The sample contains three groups of students: those in grade 9 aged 15, those in grade 9 not aged 15 and those aged 15 not in grade 9. The PISA weighting procedure ensured that these differential sampling rates were taken into account when analysing the 15-year-old samples, grade 9 and others combined (for more details, see the PISA 2000 Technical Report, pp. 190).
} 
abroad). Based on this definition, the Swiss students represent $79.6 \%$ of our sample, secondgeneration immigrants $9.3 \%$ and first-generation immigrants $11.1 \%$.

Table 2 describes the country of birth for the students and their parents. In our sample of 7790 students, the majority of Swiss were born in Switzerland (97\%) while very few were born abroad (3\%). Among immigrant students, the countries of origin differ considerably between second and first-generation but most of the time, both parents were born in the same country. Second-generation immigrants are most likely to come from Italy, Spain, France or Germany (in almost one out of two cases) while first-generation immigrants are most likely to come from former Yugoslavia, Albania or Kosovo (in fifty percent of cases). All students have been residing in Switzerland for at least 12 months.

\section{Descriptive statistics}

The reading, mathematics and science achievement distribution by immigrant status for the $9^{\text {th }}$ graders are presented in Figures 1 to 3 . Students obtain on average 499 points in reading literacy, 536 points in mathematics literacy and 498 points in science literacy. Both first and second-generation students score significantly below their Swiss peers. Compared to the Swiss students, second-generation immigrants perform on average 54 points below in reading, 63 points below in mathematics and 66 points below in science. First-generation immigrants perform on average 94 points below in reading, 87 points below in mathematics and 99 points below in science. ${ }^{5}$

The literature on education and migration generally focuses on three assumptions to explain why immigrants' students perform poorly in a host country compared to the native students. First, the language hypothesis suggests that immigrant students perform worse because they don't speak the language of the test at home. However, existing empirical evidence is not unanimous on this. Using PISA 2000 in nine countries (France, Finland, Germany, United Kingdom, Sweden, Australia, Canada, New Zealand and the US), Entorf and Minoiu (2005) find that migrant students improve significantly their reading proficiency scores when the language spoken at home is the national language as opposed to some foreign language. Using three international databases (TIMSS 1995 and 1999, PIRLS $2001^{6}$ and PISA 2003) in ten OECD countries (Germany, Switzerland, Netherlands, Sweden, France, USA, UK, New Zealand, Australia and Canada), Schnepf (2007) finds that language skills seem to explain immigrants' disadvantage in English-speaking countries whilst socioeconomic background and school segregation are further important determinants of immigrants' gap in Continental Europe. However, as mentioned before, the international sample lumps together students from different grades (7 to 9) because of the decentralized structure of the Swiss educational system. Then, one should be cautious in interpreting results that use the international sample in the case of Switzerland. The weighted summary statistics of the PISA national sample are presented by immigration status in Table 3 . While $94 \%$ of the Swiss report speaking the language of the test at home (e.g., either French in the Frenchspeaking part, German in the German-speaking part or Italian in the Italian speaking-part), this is the case for only $36 \%$ of second-generation immigrants and $19 \%$ of first-generation immigrants.

Second, the background hypothesis states that immigrants' students perform worse because they have a detrimental socio-economic background relative to the native students. Using the

\footnotetext{
5 A difference of 70 score points represents one proficiency level on the PISA 2000 reading scales (FSO 2002, p. 24).

6 PIRLS 2001 (Progress in International Reading Literacy Study) is an international comparative study of the reading literacy of students in thirty five countries. PIRLS focused on primary school children attending grade 4 (aged 9-10 years) while TIMSS and PISA assessed children in secondary school.
} 
2000 PISA database for Germany, Ammermueller (2007) analyses the gap in test score between natives and immigrants. Whilst the author does not distinguish between first and second-generation immigrants, he argues that German students perform better than immigrants because they have a more favourable family background, particularly in the lower part of the test score distribution. In the literature, a mother's education has been found to relate positively with her children's achievement (Leibowitz, 1974; Murnane et al., 1981). Moreover, parental education is also a way to control for potential intergenerational educational transmission (Gang and Zimmermann, 2000; Belzil and Hansen, 2003). In Switzerland, Bauer and Riphahn (2007) investigate the patterns of intergenerational education transmission for natives and second-generation immigrants with the 2000 Census. They find that children disadvantaged by parental background have only limited opportunities to catch up educationally. Evidence also shows that children who grow up in a low-income family tend to have lower educational attainments (Haveman and Wolfe, 1995). In our sample, 56\% of mothers of Swiss students have successfully completed post-compulsory studies when only $32 \%$ of second-generation immigrants' mothers and $24 \%$ of first-generation immigrants' mothers fulfill this criterion. ${ }^{7}$ Since parental income is not available in the PISA database, we use the International Socio-Economic Index of Occupational Status (ISEI) ${ }^{8}$ as a proxy. ISEI is derived from student responses on parental occupation. Value on the index range from 16 to 90; low values represent low socio-economic status while high values represent high socioeconomic status. Finally, in order to control for home resources we also use the number of books at home as a proxy for family expenses in cultural goods.

Third, the environment hypothesis argues that immigrants' students perform worse because they do not attend the same learning environment as their native counterparts (Entorf and Lauk, 2008). Though this is still being debated, recent empirical evidence tends to confirm that school inputs can influence achievement (Rivkin et al., 2005). School inputs include a measure of school size (the full number of pupils registered in the school) and a proxy for class size (the school/teaching staff ratio). Teacher input includes the proportion of teachers with an ISCED 5 in pedagogy. ${ }^{9}$ Inputs related to environment of the school are the degree of urbanization of the school location and sub-national entity dummies (e.g. Cantons). All these variables are at the school level. The information is extracted from the school questionnaire completed by school principals. Even if the students do not have the choice for the school in Switzerland, descriptive statistics show that immigrants are on average more likely to frequent bigger schools, less likely to have a teacher with an ISCED 5 in pedagogy and more likely to concentrate in schools located in towns or cities. ${ }^{10}$

Finally, we include traditional individual characteristics such as the student's gender and his age. ${ }^{11}$ Available evidence shows a gender gap in achievement that is generally in favor of

\footnotetext{
7 In the student's questionnaire, two questions are related to the mother's education (and the same questions for the father). The first question is about the mother's secondary education and students have the choice between: 1) none (did not go to school), 2) completed primary education (4 to 6 years of schooling), 3) completed lower secondary education (7 to 9 years of schooling), 4) completed vocational or prevocational upper-secondary education or 5) completed upper secondary education. The second question is about the mother's tertiary education and students have the choice between: 1) yes or 2) no. Because some inconsistencies appear among the answers of those two questions, only the answers related to the mother's secondary education are used in the analysis.

8 For more information on the methodology, see Ganzeboom et al. (1992).

9 ISCED (International Standard Classification of Education) level 5A is the first stage of tertiary education.

${ }^{10}$ The proportion of foreign-born population varies widely from one area to another, in particular according to the degree of urbanization: from $8 \%$ (Uri) to $38 \%$ (Geneva). It is particularly high in large cities (OFS, 2005). Uri is a rural Canton (Altdorf, the local capital, has a population of 8517 habitants) and Geneva is almost fully urbanized.

${ }^{11}$ In the student questionnaire, the question regarding age is: "which is your day, month and year of birth"? There is also a question regarding the length of residence in Switzerland: "how long have you been living in Switzerland (in years)"? First, the variable related to age has 35 missing values while the variable related to the
} 
female students in reading and of male students in mathematics and science (Marks, 2008 ; Guiso et al., 2008). Since all students are in grade 9, age allows us to control for repeating a scholar year. We introduce the family structure and the number of sibling to control for family size effects (Wolter and Coradi Vellacott, 2003).

Our analysis suffers from some data limitations. First, not all factors important for the explanation of reading, mathematics and science literacy can be taken into account. For example, we would like to capture the effects of the composition of schools in terms of migrant population. Unfortunately, information related to the peers at class or school level is not available. Second, missing values are an important feature of the data. Table 3 reports the percentage of missing values for each variable used in the estimations. While some variables such as gender have no missing values, others such as the education level of parents or some school characteristics have a substantial number of missing values. Ideally, we would like to minimize attrition especially, if it is correlated with the immigration status. For that reason, we work with two samples. In a first sample (sample 1), we flag the missing values in order to keep the sample size as large as possible while in a second sample (sample 2), we run regressions only for students who did answer to all questions of interest. Third, ideally we would like to exploit the heterogeneity of the education system among Cantons. By design, the national sample allows comparisons among the three linguistic regions (German, French, Italian) but not among the 26 Cantons. This is because the subsamples are meant to be representative at the linguistic level but not at the Canton level. We do, however, control for unobserved Canton characteristics by including Canton dummies in some regressions. ${ }^{12}$

\section{Empirical strategy}

The achievement of a given student at a particular point in time is a function of the cumulative inputs of family, peers or other students, and school and teachers (Hanushek, 1986). Unfortunately, while the PISA 2000 study contains detailed information about the student's family and school characteristics, some inputs are unobservable or missing. The use of proxy variables allows to accounting (at least in part) for unobservable characteristics. They must be correlated with omitted inputs to diminish omitted variables bias (Todd and Wolpin, 2003).

We use educational production functions (EPF) to estimate the impact of aforementioned characteristics on individual test scores. The impact of individual, family and institutional characteristics on individual pupils can be measured by an education production function in its general form as follows:

$$
\text { Test score }=\beta Z_{i}+u_{i}
$$

where "Test gonmen " represents a schooling output measure for the $t^{\text {th }}$ student $(i=1, \ldots, n), \boldsymbol{R}$ is a vector of coefficients, $Z_{i}$ is a vector of individual characteristics (immigration status, age, language spoken at home and gender), family background (family structure, number of siblings, parental level of education, ISEI score and number of books at home), school characteristics (school size, school/teacher ratio and the proportion of teachers with a ISCED

\footnotetext{
length of residence has 380 missing values. Second, age is more precise (day, month, year) than the length of residence (years). Third, age and length of residence should be equal (if the pupil is born in Switzerland) or greater (if the student is born abroad and has move to Switzerland later in his life) but cannot be lower (a student cannot be stayed more months in Switzerland than his age). However, we observe that almost one third (2616 out of 7790 students) declare having an age lower than their length of residence. For all these reasons, the variable "length of residence" is too noisy to be useful and we do not use it as a control.

${ }^{12}$ Note that two Cantons (Appenzell inter Rhodes and Uri) did not participate to the PISA 2000 assessment.
} 
5 level in pedagogy) and school environment (school location and Cantons) and $u_{i}$ is the error term.

\section{Results}

Table 4 reports the association of immigrant status and reading, mathematics and science literacy in grade 9, with no additional controls in the model. Not surprisingly, immigrants perform worse than the Swiss. Moreover, first-generation immigrants are more disadvantaged than second-generation immigrants. The inclusion of school fixed effects (to control for unobserved characteristics) tends to reduce the coefficient of immigrant status, implying that immigrants are located in schools with lower average performance.

Table 5 reports regression results with additional controls for individual characteristics, family background and school characteristics. Results show that the impact of immigrant status is substantially smaller for both second and first-generation immigrants but remains sizeable for first-generation immigrants in reading $(-4.5 \%)$, mathematics $(-6 \%)$ and science ($7.7 \%$ ). Gender also plays a significant role in achievement. Females obtain better results in reading literacy $(+3.4 \%)$ than their male counterparts but perform worse in mathematics literacy $(-4.8 \%)$ and science literacy $(-4.5 \%)$. Age is negative and significant. In addition, we may be under-estimating the effect of age as those with missing values on this variable $(14 \%$ of our sample in reading) have significantly lower test scores. Speaking the language of instruction at home is associated with significantly higher scores $(+4.4 \%$ in reading, $+4.4 \%$ in mathematics and $+4.2 \%$ in science).

Do immigrant students perform worse because they don't speak the language of the test at home? While the language spoken at home may be the result of an educational family choice for many Swiss or second-generation students, this is certainly not the case for firstgeneration immigrants. In order to disentangle the specific effect of not speaking the language of the test at home for immigrant students, we also run the estimates with an interaction term between the immigrant status and the language of the test. We report the results with the interaction variable between the first-generation immigrants and the language spoken at home in Table 6 and those with the interaction variable between the second-generation immigrants and the language spoken at home, in Table 7. In both case, all the coefficients associated to the immigrant status and the language spoken at home remain significant and consistent while the interaction terms are not significant in reading and mathematics. These results argue that speaking another language than the language of the test is not more penalizing for immigrant students.

When we explore the role of family backgrounds and their association with performance, the results indicate the importance of family structure $(+1.6 \%$ in reading if the student lives in a nuclear family) and the number of siblings (-1.2\% in reading for each added sibling). The education of the mother is positive and significant especially when she completed a degree higher than lower secondary $(+6.2 \%$ in reading if the mother completed an upper secondary level). The results for the education of father are not significant (except in reading for vocational or prevocational upper secondary) but the proxy for the economic situation of the family (ISEI) is positive and significant. Finally, the number of books at home is also positive and significant $(+11 \%$ in reading if the number of books at home is 501 or plus compared to having between none and 10 books at home). The returns to the number of books at home should also be taken with caution as the immigrants' families are probably less likely to have many books at home if they have moved to Switzerland recently.

Do immigrant students perform worse because of their socio-economic background? There is no reason to expect a stronger effect of the mother's education on immigrants than on natives. However, the returns to the mother's education must be taken with caution as having 
achieved an upper secondary level in a foreign country might mean something different from having achieved the same attainment level in Switzerland. To test this idea, we run separate specifications in which we add an interaction term between the immigrant status (firstgeneration and second-generation separately) and the variables used as proxy for the family background (only the significant one in Table 5). The results (not reported) confirm our expectation as the interaction terms with the family structure, mother's education, ISEI or the number of books at home, are all non significant. By contrast, the interaction variable between the first-generation immigrant and the number of siblings is negative and significant for reading and mathematics literacy (see Tables 8 and 9). It means that having one more sibling for a first-generation immigrant has a negative impact on reading or mathematics literacy. The main effect of being a first-generation immigrant is no more significant in this case. This result suggests that the size of the family is particularly penalizing for firstgeneration immigrant and that first-generation immigrants belong to large families.

Further analyses were finally conducted to examine the role of school characteristics and of the school environment. Studying in a school with a high proportion of teachers with an ISCED 5 level in pedagogy has a massive positive impact on literacy $(+15.5 \%$ in reading, + $14.6 \%$ in mathematics and $+16.7 \%$ in science). Moreover, we may be under-estimating the effect of the proportion of teachers with an ISCED 5 in pedagogy as students with missing values on this variable ( $12 \%$ of our sample in reading) have significant higher test scores. The proportion of teachers with an ISCED 5 in pedagogy may be endogenous if the decision taken by a higher educated teacher to teach in a specific school is correlated with unobservables that affect test scores. Descriptive statistics show that higher educated teachers are more likely to teach in large towns than in villages or small towns or in French-speaking Cantons than in German or Italian-speaking Cantons but there is no such pattern with the school size or with the school teacher ratio. Therefore, we also run equation (1) with an interaction term between the immigration status and the proportion of teachers with an ISCED 5 in pedagogy but the interaction variable is not significant.

Finally, the school size and the school size/number of teachers' ratio have a significant but minor impact. The school location is not significant and the results about Cantons are difficult to interpret but we include them as a control for unobserved characteristics related to Canton specificities.

\section{Robustness checks}

These results are robust to a number of specifications. First, we re-estimate equation (1) with the Balanced Repeated Replication (BRR) procedure recommended by the OECD. This procedure does not change the coefficients but increases the standard errors. Second, we reestimate equation (1) with linguistic region dummies instead of the Cantons. Compared to students in German-speaking Cantons, those in French-speaking Cantons perform significantly worse (Italian-speaking Cantons is not significant). Third, we finally re-estimate equation (1) with a restricted sample (i.e. sample 2). The sample sizes are indeed smaller and consist of 5774 students for reading literacy, 3187 students for mathematics literacy and 3221 students for science literacy. All results confirm the qualitative findings obtained with the previous estimations.

\section{The achievement gap between Swiss and immigrant students in reading literacy}

We focus now on the achievement gap in literacy between the Swiss and the immigrant students. First, the analysis of the impact of immigrant status on achievement provide interesting but insufficient explanations for understanding the sources of achievement gap 
between natives and immigrants. Second, it is not clear so far whether the achievement gap between natives and immigrants is constant along the distribution of test scores. This is important as the impact of immigrant status is generally analysed at the mean only.

Some studies provide alternative strategy for analyzing achievement gap along the distribution. In a cross national context, Schnepf (2008) examines the immigrants' educational disadvantage in eight high immigration countries (Australia, Canada, Germany, New Zealand, Sweden, Switzerland, UK and USA). Using quantile regression, the author argues that language skills impact more on educational achievement at lower percentiles than at the top of the achievement distribution. Using an extended version of PISA 2000 data for Germany, Ammermueller (2007) focuses on student performance of natives and immigrants with the so called Juhn, Murphy and Pierce (JMP) decomposition. Using a specific PISA 2000 sample for Copenhagen (Denmark), Rangvid (2007) focuses on the potential sources of immigrant-native test score gap. Analyzing the raw ethnic test score gap, the author finds that schools attended by immigrant students have less well developed culture of achievement.

\section{Graphic analysis of achievement gap}

Figure 4 plots the reading literacy score gap along the distribution. In this section, we focus only on the reading literacy for sample size reasons as discussed above. The dotted line plots the reading literacy score gap between Swiss and first-generation immigrants on the y-axis against the percentile of each distribution on the x-axis. The score gap between Swiss and first-generation immigrant students is much higher for the weakest pupils (about 105 points for the $5^{\text {th }}$ percentile) than for those at the top of the distribution (about 66 points for the $95^{\text {th }}$ percentile). Moreover, while the gap remains more or less constant for the first half of the distribution (between 100 and 105 points), it decreases in the second half. We observe a similar pattern for the score gap between Swiss and second-generation immigrants (plain line of Figure 4). However, the gap is smaller: around 60 points in the first half of the distribution, then decreasing to about 40 points at the end of the distribution. Overall, these results suggest that migratory origin is less penalizing for good students.

\section{Empirical strategy}

The empirical strategy used in this section is the methodology introduced by Juhn, Murphy and Pierce (1993) because it has two advantages. First, this technique measures the decomposition of between-group differences in the full distribution rather than at the mean only. Second, the JMP methodology allows for an exhaustive decomposition of the differential of test scores between Swiss and immigrants into elements driven by individual characteristics, elements driven by different returns to these characteristics and 'unobservables'. The working hypothesis for the empirical strategy so far has been that students across the two groups (Swiss vs. immigrant) are identically treated by the educational system. Then, we would expect to find that the score differential between a native and an immigrant student is entirely attributable to differing endowments.

To test the assumption according to which coefficients are different between the two distinct demographic groups, we estimate equation (1) separately for each sub-group under consideration:

$$
\begin{aligned}
& \text { Test score } e_{i}^{n}=\beta^{n} Z_{t}^{n}+u_{t}^{n} \\
& \text { Toat acor } \alpha_{i}^{m}-\beta^{m} Z_{i}^{m}+u_{t}^{m}
\end{aligned}
$$


where $n$ and $m$ represent natives and immigrants, respectively. The error term for group $n$ in (2), $u_{i}^{n}$, is the component of test scores accounted for by the unobservables. The working assumption is that this residual has two components: the percentile of an individual residual in the residual distribution ( $\left.\theta_{t}^{n}\right)$ and the distribution function of the EPF equation residuals, $F^{m}($ ) $)$. By definition of the cumulative distribution function:

$$
u_{t}^{n}=F^{n(-1)}\left(\theta_{t}^{n} \mid Z_{t}^{n}\right)
$$

where $\left.F^{m(-1)} C_{n} \mid Z_{t}^{n}\right)$ is the inverse cumulative residual distribution.

In this framework changes in inequality in terms of the score gap come from three sources: changes in the 'quantities' of individual characteristics ( $Z$ 's), changes in the 'prices' of observables characteristics ( $\beta$ 's) and changes in the distribution of the residuals $(u) .{ }^{13}$ Using the estimated coefficients from equations (2), we can determine the actual distribution of reading scores and two hypothetical distributions for each considered groups:

$$
\begin{aligned}
& \text { Test score } e_{i}^{n}\left(A_{1}\right)=\beta^{n} Z_{t}^{n}+F^{n(-1)}\left(\theta_{t}^{n} \mid Z_{t}^{m}\right) \\
& \text { Test score } \theta_{i}^{m}\left(A_{2}\right)=\beta^{m} Z_{t}^{m}+F^{m(-1)}\left(\theta_{t}^{m} \mid Z_{t}^{m}\right) \\
& \text { Test score } \theta_{i}^{m}\left(H_{1}\right)=\beta^{m} Z_{t}^{m} \mid F^{n(-1)}\left(\theta_{i}^{n} \mid Z_{t}^{n}\right) \\
& \text { Test score } \theta_{t}^{m}\left(H_{2}\right)=\beta^{m} Z_{t}^{m}+F^{m(-1)}\left(\theta_{t}^{n} \mid Z_{t}^{n}\right)
\end{aligned}
$$

Equations (4a) and (4b) show the actual distributions for natives and immigrants with varying quantities $\left(Z\right.$ 's), varying prices $\left(\beta\right.$ 's) and a varying residual distribution $\left(F^{\prime}(\cdot)\right)$. Equation (5) shows the hypothetical outcome with varying quantities but fixed prices and a fixed residual distribution. ${ }^{14}$ This equation states what the distribution of the scores of immigrants would be if they used the education production process of natives and drew their residuals from the natives' residual distribution. Equation (6) shows the hypothetical outcome with varying quantities, varying prices but with a fixed residual distribution. This equation illustrates what the distribution of the scores of immigrants would be if their residual distribution were identical to that of the natives.

The total difference can be attributed to differences in observable quantities or characteristics effect, differences in observable prices or return effect and differences in unobservable quantities and prices or residual effect. The effect of characteristics is the difference between the test score distribution for $\mathrm{A} 1$ and $\mathrm{H} 1$ while the return effect is the difference between the test score distribution for $\mathrm{H} 1$ and $\mathrm{H} 2$. Finally, the residual effect if the difference between the test score distribution for $\mathrm{H} 2$ and $\mathrm{A} 2$.

\section{Results}

We first present the results for the total score gap between Swiss and second-generation immigrants. Figure 5 breaks down the total score gap between Swiss and second-generation immigrants into the characteristics effect, the return effect and the residual effect (for detailed results, see Table 10). If the structure of both groups was the same for observable

\footnotetext{
${ }^{13}$ This terminology is inherited to the labour economics literature. Changes in the 'quantities' means changes in the distribution of the $Z$ 's and changes in the 'prices' of observable characteristics means changes in the distribution of the $\beta$ 's.

${ }^{14}$ The reference group is the Swiss. Estimated coefficients from Swiss' regression are used as reference 'prices'. Residuals from the Swiss regression are used to determine the reference residual distribution.
} 
characteristics, any score differential could only result from differences in the return of these characteristics (or from a difference in the residual effect). Conversely, if the return was similar then the score differential would result entirely from characteristics effect. The total reading literacy score gap between Swiss and second-generation immigrants is almost entirely explained by differences in endowments $(89.5 \%$ on average). Moreover, this is the case all along the distribution, meaning there is no difference between the weakest (i.e. the lower half of the distribution) and the best students (i.e. the upper half of the distribution).

Figure 6 illustrates the total score gap between Swiss and first-generation immigrants. On average, the total score gap is also mainly explained by differences in endowments between Swiss and first-generation immigrant (82\%). However, differences in endowments are less important for explaining the reading score gap in the lower half of the distribution (from $66 \%$ for the $5^{\text {th }}$ percentile to $86 \%$ at the median). Indeed, the return effect accounts for around one quarter of the total score gap for the two lowest percentiles (i.e. $5^{\text {th }}$ and $10^{\text {th }}$ ). This result means that one part of the total score gap for the weakest students comes from the fact that the individual characteristics of first-generation immigrant yield lower return.

Different reasons can be advanced to explain the importance of the return effect for the weakest student in reading literacy. For example, some variables, such as the mother's education, are not measuring the same effect for Swiss and first-generation immigrants. This could be the case if the schooling level achieved in a foreign country by an immigrant's mother is not equivalent to the same schooling level achieved in Switzerland by a Swiss mother. Another could be that differences in treatment exist between Swiss and firstgeneration immigrants in the schooling system. Unlike at primary school, the students are oriented across different streams according to ability and learning at the beginning of the secondary (i.e. grade 7). Almost all secondary schools in Switzerland have different types of secondary education or offer a combination of different streams in different fields. Due to the decentralized structure of the educational system, the Cantonal combinations are grouped at national level into five lower secondary school types: school preparing for university entry, streams with wider demands, streams with basic demands, streams without selection and special education programs. Not all Cantons offer all these five categories (e.g. only four Cantons offer streams without selection). Descriptive statistics based on our national sample (i.e. 7790 students) show that most students attend streams with wider demands $(37.83 \%)$, followed by streams with basic demands $(27.32 \%)$, schools preparing for the university entry $(22.27 \%)$, streams without selection $(12.11 \%)$ and special education programs $(0.47 \%)$. However, we observe huge difference between Swiss and immigrants. The Swiss are more likely to attend the "best streams" (40.74\% attend streams with wider demands and $23.98 \%$ attend school preparing for the university entry) than second-generation immigrants $(31.25 \%$ and $19.31 \%$ respectively) and first-generation immigrants $(21.66 \%$ and $12.03 \%$ respectively). If immigrant students are systematically oriented to lower streams, this can explain why some of their characteristics yield to lower returns. Obviously, this argument needs further investigation and requires longitudinal database in order to analyze how immigrant students (especially first-generation immigrants) are oriented and integrated into the Swiss educational system.

Finally, in both cases, the residual effect has the smallest effect (between $0.4 \%$ and $0.8 \%$ on average). Along the distribution, its impact remains small (around $+5 \%$ for the $5^{\text {th }}$ and $10^{\text {th }}$ percentiles) and becomes negative at the $75^{\text {th }}$ percentile. This result means that unobserved quantities and prices are decreasingly important when we move along the distribution.

\section{Robustness checks}


Our results are sensitive to the specifications we use for the estimations as the JMP decomposition uses in particular the $\beta$ 's estimated separately for Swiss and immigrants (first or second-generation). We re-estimate the JMP decomposition between Swiss and firstgeneration immigrant with the individual characteristics, the family background and the school's characteristics separately. Results with individual characteristics only (age, gender and language spoken at home) show that differences in returns explain $2 / 3$ part of the total score gap in reading literacy against $1 / 3$ for the characteristics effect. This is the case all along the distribution but particularly so in the upper half of the distribution.

Results with family background variables only (family structure, number of siblings, parental education, ISEI and number of books at home) show that total score gap in reading literacy is half explained by differences in endowments (characteristics effect) and half explained by differences in return of these characteristics (return effect). However, the return effect dominates the characteristics effect for the lowest percentiles $\left(5^{\text {th }}\right.$ and $\left.10^{\text {th }}\right)$ and for the upper percentiles $\left(90^{\text {th }}\right.$ and $\left.95^{\text {th }}\right)$.

Results with school characteristics only (school size, school/teacher ratio, proportion of teacher's with ISCED 5 in literacy and Cantons) show that differences in returns explain the most part of the total score gap in reading literacy (i.e. 4/5 against 1/5 for the characteristics effect).

Finally, we re-estimate the JMP decomposition with the restricted sample (sample 2). The results confirm findings obtained with the larger sample (sample 1).

\section{Conclusion}

The primary purpose of this research is to investigate the impact of immigrant status on reading, mathematics and science literacy for Switzerland. Based on the national option to the PISA 2000 database, the results show that immigrant students perform less than Swiss students even after controlling for individual characteristics, family background and school characteristics. The negative impact of immigrant status is more important for first-generation immigrants than for second-generation immigrants.

The use of interaction terms between immigrant status (second-generation and firstgeneration separately) and some other variables of interest sheds light on interesting patterns allows refining the results. First, speaking a language at home different from the language of the test is no more penalizing for immigrant students than for the Swiss. Second, among the socioeconomic characteristics of first-generation immigrants, only the number of siblings is particularly penalizing. These results suggest that poor results of immigrant students in Switzerland are the result of a set of characteristics (such as lower language skills, less educated parents, lower family income, etc.) rather than the immigrant status by itself.

The second purpose of this research is to investigate the achievement gap in literacy between Swiss and immigrant students. This way, we examine the hypothesis according to which lower performance of immigrant students are generally attributed to lower endowments. Using the Juhn, Murphy and Pierce decomposition permits analyzing betweengroup difference in the full distribution rather than at the mean only (as in the first part of the paper). This is important as the achievement gap between Swiss and immigrants is decreasing along the distribution of scores.

Two noteworthy features of the composition of the gap emerge. First, lower endowments explain on average almost $90 \%$ of the achievement gap in reading between Swiss and secondgeneration immigrants. Moreover, there is no difference between the weaker and the better half of students. Second, lower endowments explain the most part of the achievement gap 
between Swiss and first-generation immigrants (around 82\%) at the mean. In that case however, lower returns explain around one quarter of the achievement gap for the weakest pupils (i.e., the two lowest percentiles).

The fact that the reading score gap of the weakest students can be to some extent explained partly by lower returns for first-generation immigrant students raises the question of educational segregation. Educational segregation tends to keep apart immigrant people in specific class, streams or schools of lower quality. Actually, descriptive statistics show that immigrants are less likely to attend the "best streams". To unveil the mechanisms of this pattern of schooling segregation, a longitudinal database with individual characteristics is needed; unfortunately, this dimension is not available in the PISA database. We leave this important question for further research. 


\section{References}

Ammermueller, A. (2007). Poor Background or Low Returns? Why Immigrant Students in Germany Perform so Poorly in the Programme for International Student Assessment. Education Economics, 15(2), 215-230.

Bauer, P., \& Riphahn, R. T. (2007). Heterogeneity in the intergenerational transmission of educational attainment: evidence from Switzerland on natives and second-generation immigrants. Journal of Population Economics, 20, 121-148.

Belzil, C., \& Hansen, J. (2003). Structural estimates of the intergenerational education correlation. Journal of Applied Econometrics, 18(6), 679-696.

Entorf, H., \& Minoiu, N. (2005). What a Difference Immigration Policy Makes: A Comparison of PISA Scores in Europe and Traditional Countries of Immigration. German Economic Review, 6(3), 355-376.

Gang, I. N., \& Zimmermann, K. F. (2000). Is child like parent? Educational attainment and ethnic origin. Journal of Human Resources, 35(3), 550-569.

Ganzeboom, H. B. G., de Graaf, P.M., \& Treiman, D.J. (1992). A Standard International Socio-Economic Index of Occupational Status. Social Science Research, 21, 1-56.

Guiso, L., Monte, F., Sapienya, P., \& Yingales, L. (2008). Culture, Gender, and Math. Science 320, 1164-1165.

Hanushek, E. A. (1986). The Economics of Schooling: Production and Efficiency in Public Schools. Journal of Economic Literature, 24, 1141-1177.

Haveman, R., \& Wolfe, B. (1995). The determinants of children's attainment: A review of methods and findings. Journal of Economics Literature, 33(4), 1829-1878.

Juhn, C., Murphy, K., \& Pierce, B. (1993). Wage Inequality and the Rise in Returns to Skill. Journal of Political Economy, 101(3), 410-442.

Leibowitz, A. (1974). Home investment in children. Journal of Political Economy, 82(2), $111-131$.

Marks, G. (2008). Accounting for the gender gaps in student performance in reading and mathematics: evidence from 31 countries. Oxford Review of Education, 34(1), 89-109.

Martin, J. (2008). Migration and the global economy: Some stylised facts, Canadian Diversity/Diversité canadienne, 6 (3), 22-25.

Murnane, R. J., Maynard, R. A., \& Ohls, J. C. (1981). Home resources and children's achievement. Review of Economics and Statistics, 63(3), 369-377.

Office fédéral de la statistique et Conférence suisse des directeurs cantonaux de l'instruction publique (2005). PISA 2003: Compétences pour l'avenir, Deuxième rapport national, Neuchâtel/Berne.

Office fédéral de la statistique (2005). Annuaire statistique de la Suisse 2005.

OECD (2002). Programme for International Student Assessment (PISA) - Manuel for the PISA 2000 Database, OECD Publishing.

OECD (2002). PISA 2000 Technical Report, OECD Publishing.

OECD (2003). Trends in International Migration - 2002 edition, OECD Publishing.

OECD (2006). Where immigrant students succeed - A comparative review of performance and engagement in PISA 2003, Paris: OECD.

OECD (2008). A Profile of Immigrant Populations in the 21st Century - Data from OECD countries, Paris.

Rangvid, B.S. (2007). Sources of Immigrants' Underachievement: Results from PISA Copenhagen. Education Economics, 15(3), 293-326.

Rivkin, S. G., Hanushek, E. A., \& Kain, J. F. (2005). Teachers, Schools, and Academic Achievement. Econometrica, 73(2), 417-458.

Schnepf, S. V. (2007). Immigrants' Educational Disadvantage: An Examination Across Ten Countries and Three Surveys. Journal of Population Economics, 20(3), 527-545. 
Schnepf, S. V. (2008). Inequality of Learning amongst Immigrant Children in Industrialised Countries. IZA Discussion Paper n`3337.

Swiss Conference of Cantonal Ministers of Education, FSO (2002). Educational Monitoring in Switzerland. Prepared for Life? Basic Competencies of Young People - National PISA 2000 Report, Neuchâtel.

Todd, P. E., \& Wolpin, K. I. (2003). On the Specification and Estimation of the Production Function for Cognitive Achievement. The Economic Journal, 113, 3-33.

Wolter, S., \& Coradi Vellacott, M. (2003). Sibling Rivalry: A Six Country Comparison. Swiss Journal of Sociology, 3, 377-398. 


\section{Figures and tables}

\section{Figure 1}

Reading achievement distribution by immigrant status

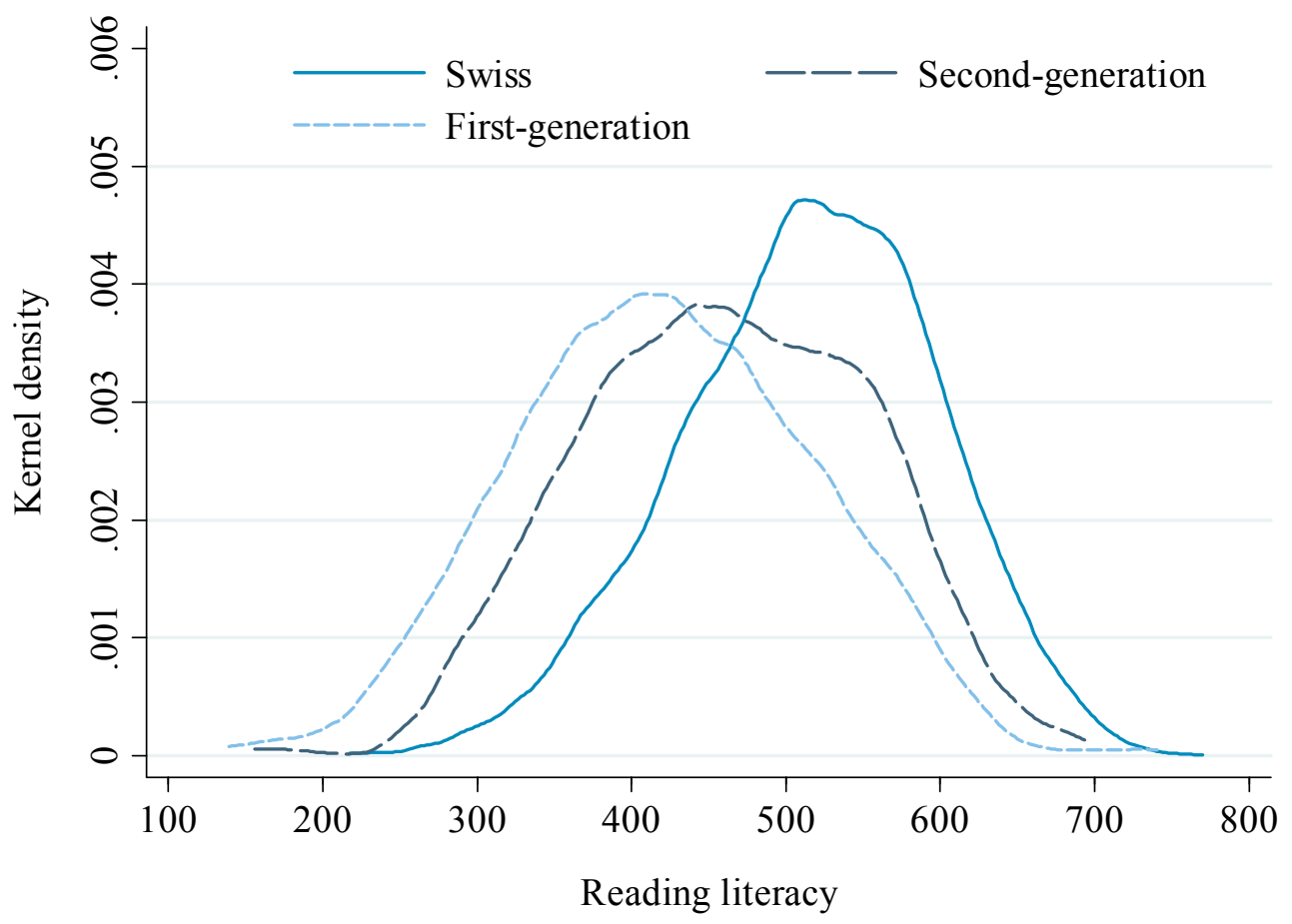

\section{Figure 2}

Mathematics achievement distribution by immigrant status

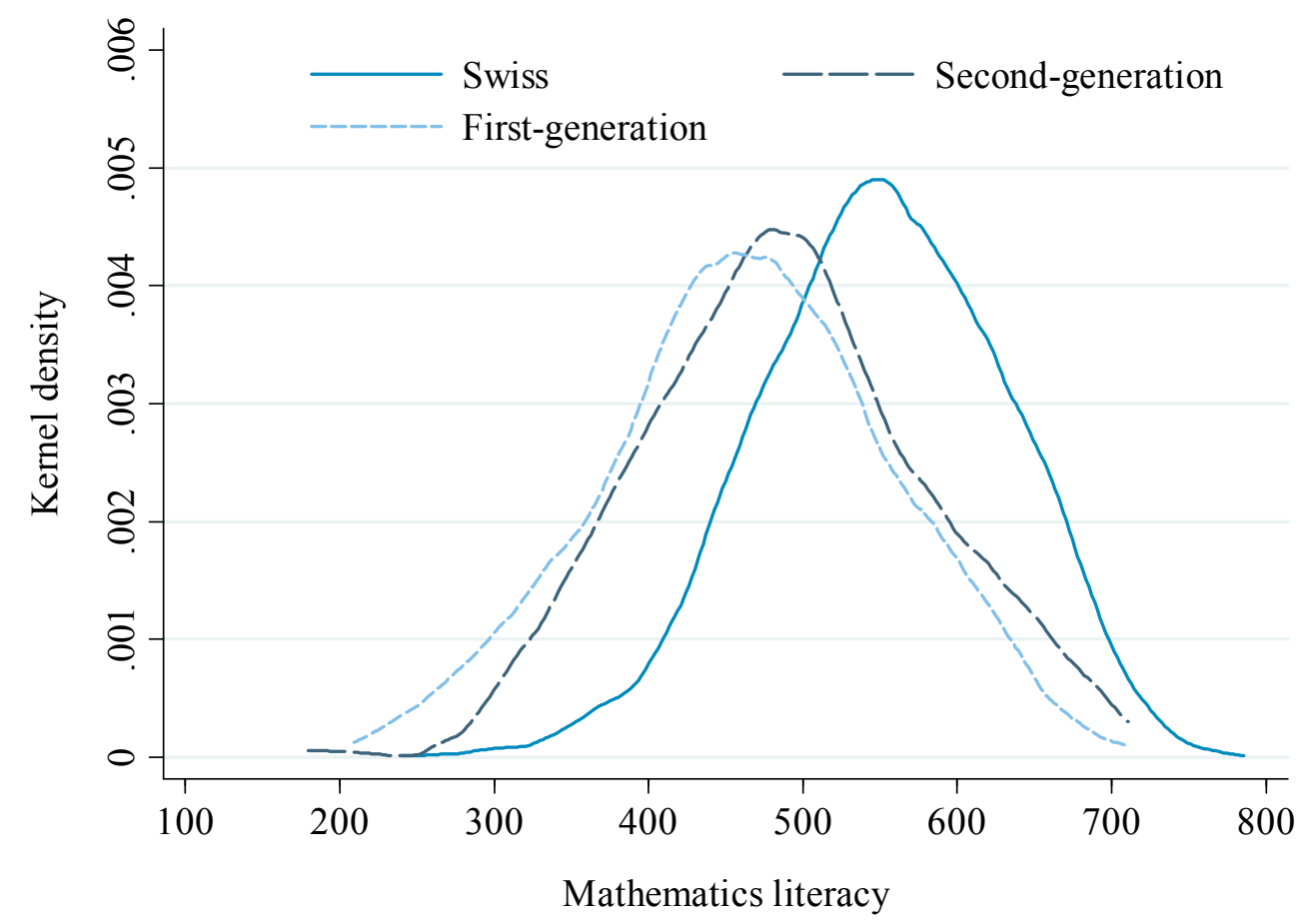




\section{Figure 3}

Science achievement distribution by immigrant status

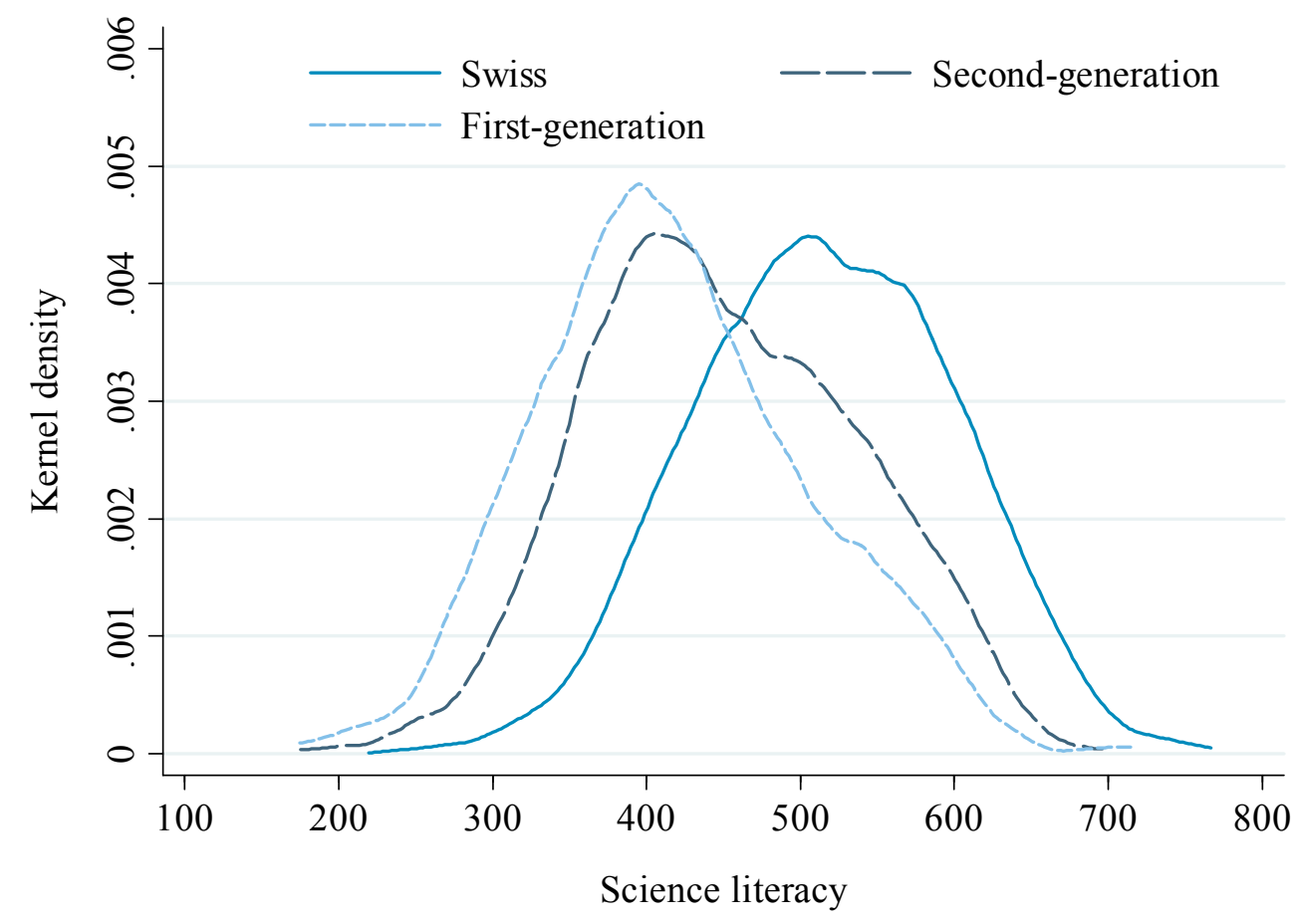

\section{Figure 4}

Reading literacy score gap along the distribution

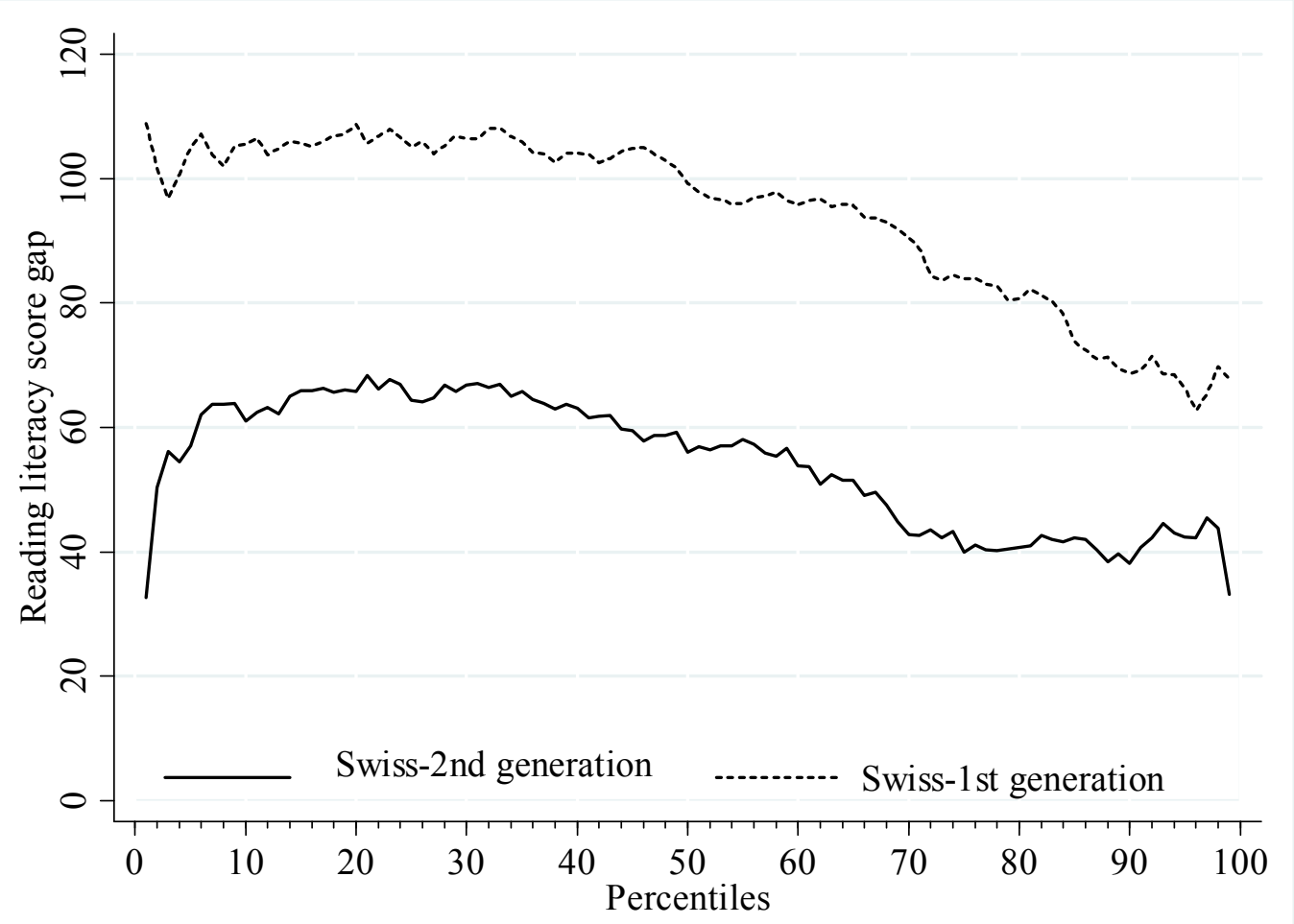




\section{Figure 5}

Total differences: Swiss vs. Second-generation immigrants

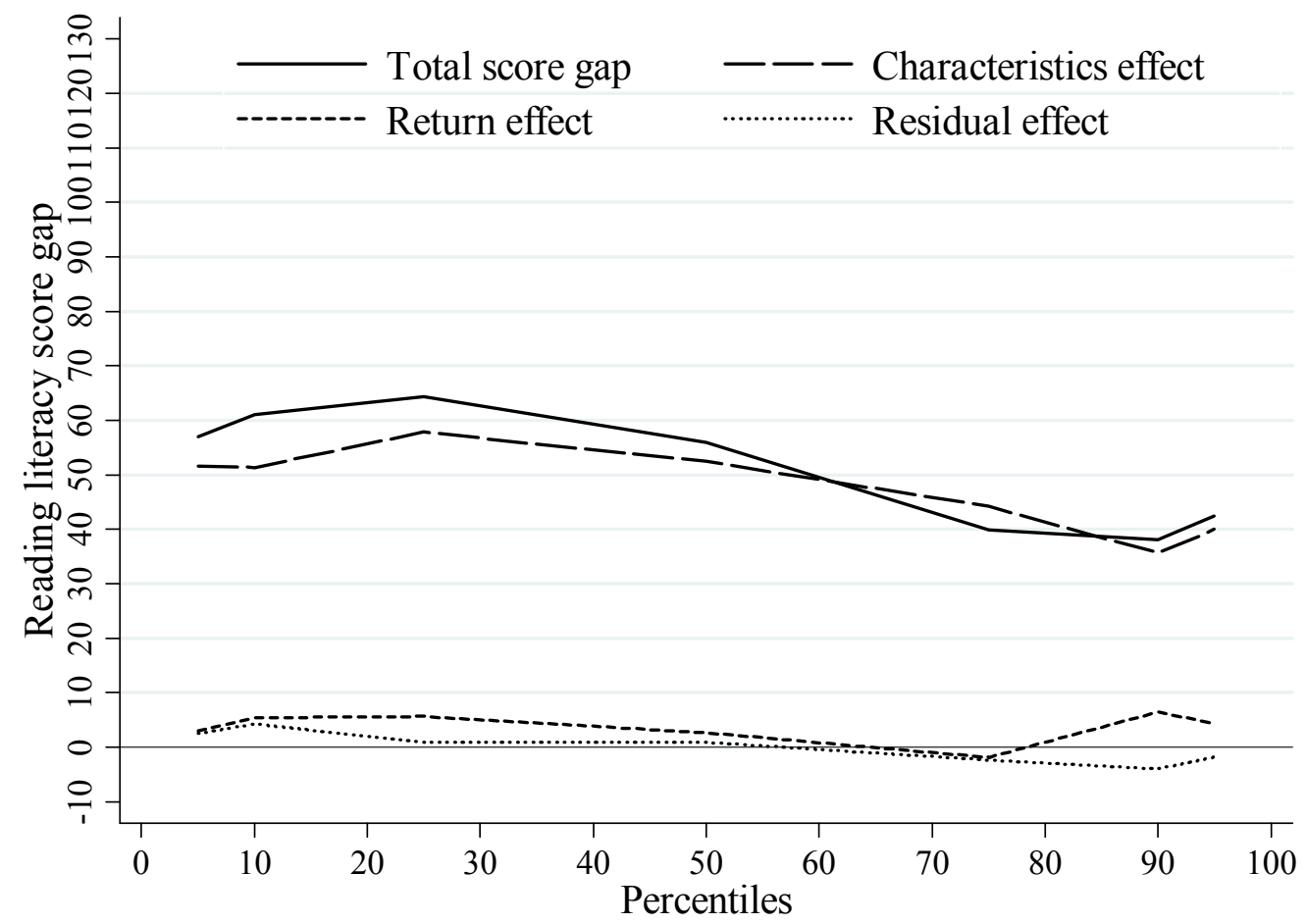

\section{Figure 6}

Total differences: Swiss vs. First-generation immigrants

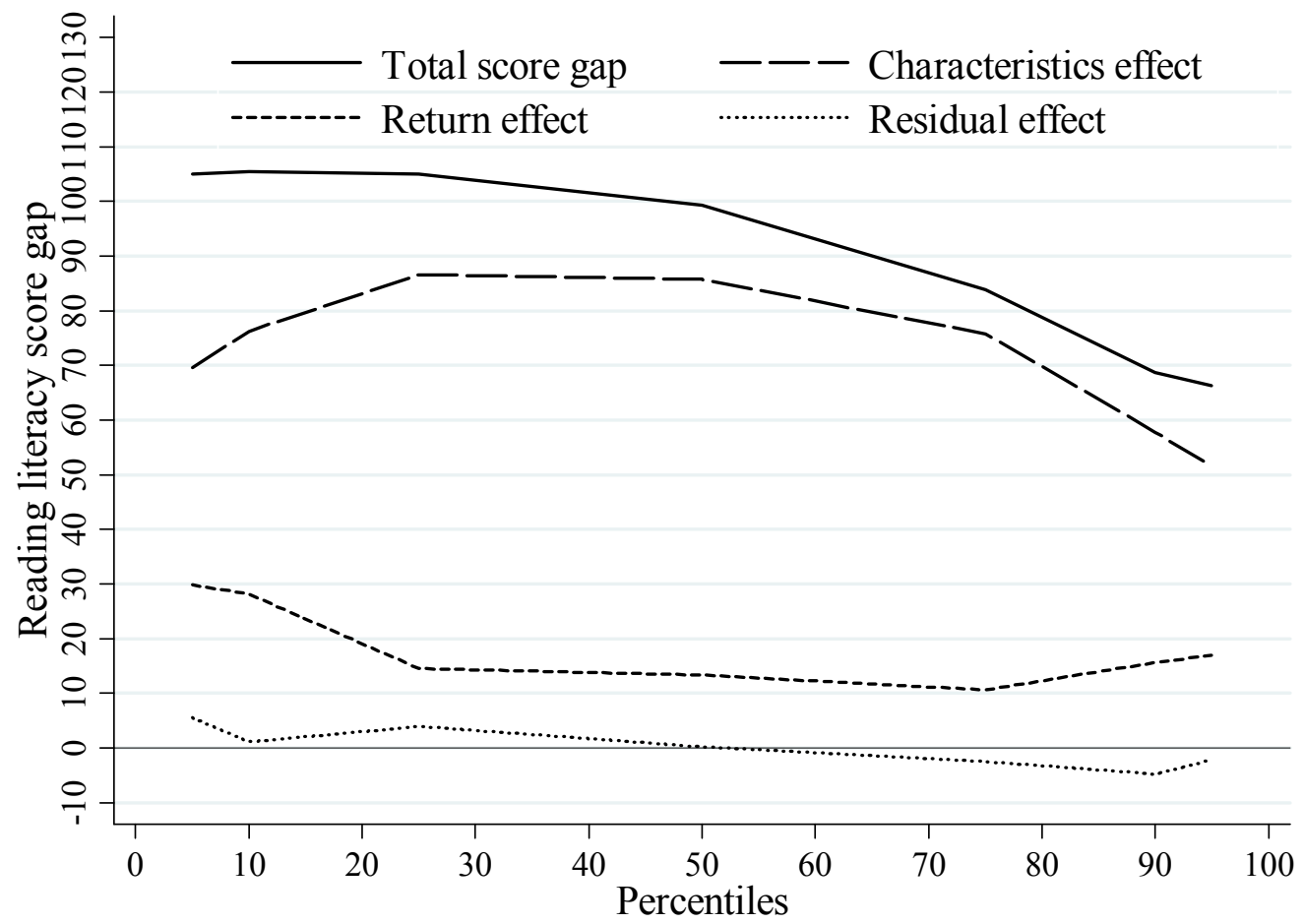




\section{Table 1}

Definition of immigrant status

\begin{tabular}{lc|c}
\hline & \multicolumn{2}{c}{ Students $(\mathrm{S})$} \\
\cline { 2 - 3 } Mother $(\mathrm{M}) \&$ father $(\mathrm{F})$ & $\begin{array}{c}\text { born in Switzerland } \\
\left(\mathrm{S}_{\mathrm{ch}}\right)\end{array}$ & $\begin{array}{c}\text { born abroad } \\
\left(\mathrm{S}_{\mathrm{a}}\right)\end{array}$ \\
\hline $\mathrm{M}_{\mathrm{ch}} \& \mathrm{~F}_{\mathrm{ch}}$ & 4955 (Swiss) & 78 (Swiss) \\
$\mathrm{M}_{\mathrm{ch}} \& \mathrm{~F}_{\mathrm{a}}$ & 559 (Swiss) & 49 (Swiss) \\
$\mathrm{M}_{\mathrm{a}} \& \mathrm{~F}_{\mathrm{ch}}$ & 509 (Swiss) & 89 (Swiss) \\
$\mathrm{M}_{\mathrm{a}} \& \mathrm{~F}_{\mathrm{a}}$ & $720\left(2^{\text {nd }}\right.$-generation immigrant) & 831 (1 -generation immigrant) \\
Total & $\mathbf{6 7 4 3}$ & $\mathbf{1 0 4 7}$ \\
\hline
\end{tabular}

Source: PISA 2000 (national sample).

\section{Table 2}

Country of birth for students and parents, by immigrant status

\begin{tabular}{lccc|ccc|ccc}
\hline & \multicolumn{3}{c|}{ Swiss } & \multicolumn{2}{c|}{ Second-generation } & \multicolumn{2}{c}{ First-generation } \\
\cline { 2 - 10 } Country of birth & $\mathrm{S}$ & $\mathrm{M}$ & $\mathrm{F}$ & $\mathrm{S}$ & $\mathrm{M}$ & $\mathrm{F}$ & $\mathrm{S}$ & $\mathrm{M}$ & $\mathrm{F}$ \\
\hline Switzerland & 6023 & 5641 & 5631 & 720 & $/$ & $/$ & $/$ & $/$ & $/$ \\
Germany/Austria & 24 & 148 & 109 & $/$ & 33 & 22 & 29 & 29 & 25 \\
France/Belgium & 19 & 90 & 67 & $/$ & 40 & 34 & 18 & 17 & 18 \\
Italy & 13 & 72 & 221 & $/$ & 240 & 272 & 59 & 60 & 68 \\
Spain & 2 & 11 & 30 & $/$ & 75 & 65 & 26 & 27 & 26 \\
Portugal & 1 & 12 & 13 & $/$ & 35 & 26 & 111 & 111 & 112 \\
Former Yugoslavia & 1 & 18 & 7 & $/$ & 87 & 82 & 266 & 266 & 264 \\
Albania/Kosovo & 2 & 2 & 1 & $/$ & 12 & 12 & 148 & 148 & 149 \\
Turkey & 2 & 3 & 10 & $/$ & 77 & 86 & 69 & 67 & 71 \\
Other country & 152 & 242 & 150 & $/$ & 121 & 121 & 105 & 106 & 98 \\
Total & 6239 & 6239 & 6239 & 720 & 720 & 720 & 831 & 831 & 831 \\
\hline
\end{tabular}

Source: PISA 2000 (national sample). Notes: student (S), mother (M), father (F). 
Table 3

Weighted summary statistics, by immigration status

\begin{tabular}{|c|c|c|c|c|c|c|c|c|}
\hline & \multicolumn{2}{|c|}{ Swiss } & \multicolumn{2}{|c|}{$\begin{array}{l}\text { Second-generation } \\
\text { immigrants }\end{array}$} & \multicolumn{2}{|c|}{$\begin{array}{l}\text { First-generation } \\
\text { immigrants }\end{array}$} & \multicolumn{2}{|c|}{ Total } \\
\hline & Mean & Std Dev. & Mean & Std Dev. & Mean & Std Dev. & Mean & Std Dev. \\
\hline Reading literacy & 514.8513 & 82.8462 & 460.5886 & 90.7585 & 420.8391 & 95.7009 & 499.3757 & 90.8762 \\
\hline Mathematics literacy (sample size: 4328) & 550.8549 & 79.6233 & 487.7693 & 90.9869 & 463.7797 & 92.5987 & 535.6060 & 87.8346 \\
\hline Science literacy (sample size: 4334) & 515.9124 & 84.1283 & 449.8647 & 85.95112 & 416.7939 & 87.0146 & 498.4319 & 91.5142 \\
\hline Age in months (min: $142-\max : 228$ ) & 188.3676 & 7.1751 & 188.3657 & 8.4514 & 192.7600 & 9.3283 & 188.8546 & 7.6915 \\
\hline Age is missing ( $\%$ of missing) & $(0.12)$ & & $(0.23)$ & & $(0.14)$ & & $(0.14)$ & \\
\hline Gender $($ female $=1$, male $=0)$ & 0.4977 & 0.5000 & 0.5259 & 0.4997 & 0.4797 & 0.4999 & 0.4983 & 0.5000 \\
\hline Language at home is the language of the test & 0.9439 & 0.2301 & 0.3604 & 0.4805 & 0.1890 & 0.3918 & 0.8107 & 0.3917 \\
\hline Language at home is missing ( $\%$ of missing) & $(2.03)$ & & $(6.17)$ & & $(6.41)$ & & $(2.90)$ & \\
\hline Family structure: nuclear & 0.7813 & 0.4134 & 0.7817 & 0.4134 & 0.8098 & 0.3927 & 0.7845 & 0.4112 \\
\hline Family structure is missing ( $\%$ of missing) & $(0.40)$ & & $(0.40)$ & & $(0.84)$ & & $(0.45)$ & \\
\hline Number of siblings (min: $0-\max : 12$ ) & 1.6278 & 1.0093 & 1.5368 & 1.0150 & 1.9581 & 1.3341 & 1.6560 & 1.0564 \\
\hline Number of siblings is missing ( $\%$ of missing) & $(0.74)$ & & $(1.03)$ & & $(0.83)$ & & $(0.78)$ & \\
\hline Educational level of mother: None or primary & 0.0198 & 0.1394 & 0.2840 & 0.4512 & 0.3466 & 0.4762 & 0.0806 & 0.2723 \\
\hline Lower secondary & 0.3525 & 0.4778 & 0.3290 & 0.4702 & 0.3401 & 0.4740 & 0.3490 & 0.4767 \\
\hline Vocational or prevocational upper-secondary & 0.3831 & 0.4862 & 0.1528 & 0.3600 & 0.1055 & 0.3074 & 0.3308 & 0.4705 \\
\hline Upper secondary & 0.1851 & 0.3884 & 0.1721 & 0.3777 & 0.1495 & 0.3568 & 0.1799 & 0.3841 \\
\hline Education level of mother is missing & 0.0595 & 0.2366 & 0.0621 & 0.2416 & 0.0582 & 0.2343 & 0.0596 & 0.2368 \\
\hline Educational level of father: None or primary & 0.0249 & 0.1557 & 0.2267 & 0.4190 & 0.2482 & 0.4322 & 0.0684 & 0.2525 \\
\hline Lower secondary & 0.3062 & 0.4610 & 0.3169 & 0.4656 & 0.2911 & 0.4545 & 0.3055 & 0.4607 \\
\hline Vocational or prevocational upper-secondary & 0.3994 & 0.4898 & 0.2098 & 0.4075 & 0.1509 & 0.3582 & 0.3542 & 0.4783 \\
\hline Upper secondary & 0.1993 & 0.3995 & 0.1640 & 0.3705 & 0.2270 & 0.4191 & 0.1990 & 0.3993 \\
\hline Education level of father is missing & 0.0703 & 0.2557 & 0.0826 & 0.2755 & 0.0828 & 0.2758 & 0.0728 & 0.2599 \\
\hline ISEI (min: 16 - max: 90) & 46.5357 & 16.8676 & 39.2159 & 15.7057 & 36.2425 & 15.1496 & 44.7849 & 16.9759 \\
\hline ISEI is missing ( $\%$ of missing) & $(2.26)$ & & $(4.91)$ & & $(8.21)$ & & $(3.16)$ & \\
\hline Number of books at home is $0-10$ & 0.0599 & 0.2373 & 0.1293 & 0.3358 & 0.2807 & 0.4496 & 0.0908 & 0.2874 \\
\hline
\end{tabular}




\begin{tabular}{|c|c|c|c|c|c|c|c|c|}
\hline Number of books at home is $11-50$ & 0.1747 & 0.3798 & 0.2660 & 0.4422 & 0.3128 & 0.4639 & 0.1985 & 0.3989 \\
\hline Number of books at home is $51-100$ & 0.2027 & 0.4020 & 0.2425 & 0.4289 & 0.1803 & 0.3847 & 0.2039 & 0.4029 \\
\hline Number of books at home is $101-250$ & 0.2355 & 0.4243 & 0.1791 & 0.3837 & 0.0892 & 0.2853 & 0.2140 & 0.4102 \\
\hline Number of books at home is $251-500$ & 0.1719 & 0.3773 & 0.0859 & 0.2804 & 0.0507 & 0.2195 & 0.1504 & 0.3575 \\
\hline Number of books at home is 501 or plus & 0.1388 & 0.3458 & 0.0866 & 0.2815 & 0.0528 & 0.2237 & 0.1244 & 0.3301 \\
\hline Number of books at home is missing & 0.0166 & 0.1276 & 0.0106 & 0.1026 & 0.0334 & 0.1798 & 0.0179 & 0.1325 \\
\hline School size (min: $24-\max : 1942$ ) & 460.1060 & 351.0586 & 545.6681 & 416.7854 & 527.8384 & 386.5345 & 475.4896 & 362.951 \\
\hline School size is missing (\% of missing) & $(6.94)$ & & $(5.80)$ & & $(9.64)$ & & $(7.13)$ & \\
\hline School/teacher ratio (min: 1.89 - max: 49.3 ) & 12.4651 & 4.1231 & 11.8074 & 2.9228 & 12.2188 & 3.7998 & 12.3774 & 3.9967 \\
\hline School/teacher ratio is missing (\% of missing) & $(8.12)$ & & $(8.52)$ & & $(11.28)$ & & $(8.51)$ & \\
\hline Proportion of teachers ISCED 5 in pedagogy & 0.5780 & 0.3317 & 0.4981 & 0.3554 & 0.5211 & 0.3495 & 0.5648 & 0.3368 \\
\hline Proportion of teachers is missing (\% of missing) & $(11.20)$ & & $(14.38)$ & & $(16.67)$ & & $(12.10)$ & \\
\hline School location is in a village (fewer than 3000 ) & 0.1480 & 0.3551 & 0.0388 & 0.1932 & 0.0919 & 0.2890 & 0.1316 & 0.338 \\
\hline Small town (3000 to 15000$)$ & 0.5358 & 0.4988 & 0.4196 & 0.4938 & 0.4291 & 0.4952 & 0.5131 & 0.499 \\
\hline Town (15000 to 100000$)$ & 0.2170 & 0.4122 & 0.3080 & 0.4620 & 0.2492 & 0.4328 & 0.2290 & 0.4202 \\
\hline City (100000 to 1000000$)$ & 0.0810 & 0.2728 & 0.2227 & 0.4163 & 0.1941 & 0.3957 & 0.1067 & 0.308 \\
\hline School location is missing & 0.0183 & 0.1339 & 0.0110 & 0.1042 & 0.0357 & 0.1855 & 0.0195 & 0.1384 \\
\hline \multicolumn{9}{|l|}{ Cantons } \\
\hline Zurich & 0.1298 & 0.3361 & 0.1949 & 0.3964 & 0.1733 & 0.3787 & 0.1407 & 0.3477 \\
\hline Bern & 0.1318 & 0.3383 & 0.0449 & 0.2073 & 0.0723 & 0.2592 & 0.1171 & 0.3216 \\
\hline Lucerne & 0.0661 & 0.2485 & 0.0641 & 0.2451 & 0.0774 & 0.2675 & 0.0672 & 0.2504 \\
\hline Schwyz & 0.0196 & 0.1385 & 0.0177 & 0.1319 & 0.0182 & 0.1339 & 0.0192 & 0.1373 \\
\hline Obwalden & 0.0367 & 0.1881 & 0.0023 & 0.0480 & 0.0212 & 0.1442 & 0.0318 & 0.1755 \\
\hline Nidwalden & 0.0070 & 0.0836 & 0.0000 & 0.0000 & 0.0031 & 0.0552 & 0.0059 & 0.076 \\
\hline Glarus & 0.0037 & 0.0609 & 0.0068 & 0.0824 & 0.0057 & 0.0755 & 0.0042 & 0.0650 \\
\hline Zug & 0.0131 & 0.1137 & 0.0242 & 0.1538 & 0.0047 & 0.0685 & 0.0132 & 0.1142 \\
\hline Fribourg & 0.0378 & 0.1908 & 0.0083 & 0.0910 & 0.0369 & 0.1887 & 0.0350 & 0.183 \\
\hline Solothurn & 0.0219 & 0.1465 & 0.0220 & 0.1469 & 0.0149 & 0.1212 & 0.0212 & 0.1439 \\
\hline Basel city & 0.0196 & 0.1385 & 0.0642 & 0.2453 & 0.0484 & 0.2147 & 0.0269 & 0.1618 \\
\hline Basel county & 0.0275 & 0.1635 & 0.0511 & 0.2203 & 0.0296 & 0.1695 & 0.0299 & 0.1704 \\
\hline Schaffhausen & 0.0083 & 0.0910 & 0.0058 & 0.0759 & 0.0032 & 0.0568 & 0.0075 & 0.0865 \\
\hline Appenzell outer rhodes & 0.0058 & 0.0762 & 0.0043 & 0.0658 & 0.0036 & 0.0603 & 0.0055 & 0.0736 \\
\hline
\end{tabular}




\begin{tabular}{lcc|cc|cc|cc} 
St Gallen & 0.0870 & 0.2819 & 0.0618 & 0.2409 & 0.0583 & 0.2344 & 0.0815 & 0.2736 \\
Grisons & 0.0297 & 0.1696 & 0.0084 & 0.0911 & 0.0113 & 0.1057 & 0.0256 & 0.1580 \\
Aargau & 0.1093 & 0.3120 & 0.0940 & 0.2920 & 0.0683 & 0.2524 & 0.1033 & 0.3044 \\
Thurgau & 0.0372 & 0.1893 & 0.0321 & 0.1764 & 0.0485 & 0.2150 & 0.0380 & 0.1912 \\
Ticino & 0.0304 & 0.1717 & 0.0621 & 0.2414 & 0.0510 & 0.2201 & 0.0356 & 0.1854 \\
Vaud & 0.0750 & 0.2634 & 0.0774 & 0.2674 & 0.0833 & 0.2765 & 0.0761 & 0.2652 \\
Valais & 0.0419 & 0.2003 & 0.0275 & 0.1636 & 0.0274 & 0.1634 & 0.0389 & 0.1934 \\
Neuchatel & 0.0180 & 0.1331 & 0.0177 & 0.1319 & 0.0271 & 0.1623 & 0.0190 & 0.1366 \\
Geneva & 0.0298 & 0.1701 & 0.1025 & 0.3036 & 0.1064 & 0.3085 & 0.0451 & 0.2075 \\
Jura & 0.0128 & 0.1126 & 0.0059 & 0.0767 & 0.0058 & 0.0759 & 0.0114 & 0.1063 \\
German-spoken region & 0.7743 & 0.4181 & 0.7001 & 0.4586 & 0.6683 & 0.4711 & 0.7556 & 0.4298 \\
French-spoken region & 0.1940 & 0.3955 & 0.2363 & 0.4251 & 0.2777 & 0.4481 & 0.2072 & 0.4054 \\
Italian-spoken region & 0.0317 & 0.1752 & 0.0637 & 0.2443 & 0.0540 & 0.2262 & 0.0372 & 0.1892 \\
Number of observations & $\mathbf{6 2 3 9}(0.7960)$ & $\mathbf{7 2 0}(0.0930)$ & $\mathbf{8 3 1}(0.1110)$ & $\mathbf{7 7 9 0}(1.0000)$ \\
\hline
\end{tabular}

Source: PISA 2000 (national sample). Notes: All observations are weighted with the students' weight. 


\section{Table 4}

The impact of immigration status on reading, mathematics and science literacy (sample 1)

\begin{tabular}{|c|c|c|c|c|c|c|}
\hline \multirow[b]{2}{*}{ Swiss } & \multicolumn{2}{|c|}{ Reading } & \multicolumn{2}{|c|}{ Mathematics } & \multicolumn{2}{|c|}{ Science } \\
\hline & ref. & ref. & ref. & ref. & ref. & ref. \\
\hline Second-generation immigrant & $\begin{array}{c}-54.2627 * * * \\
(5.6933)\end{array}$ & $\begin{array}{c}-41.6108 * * * \\
(3.5015)\end{array}$ & $\begin{array}{c}-63.0855^{* * *} \\
(7.2142)\end{array}$ & $\begin{array}{c}-51.1531 * * * \\
(5.6880)\end{array}$ & $\begin{array}{c}-66.0476 * * * \\
(6.0986)\end{array}$ & $\begin{array}{c}-51.4521 * * * \\
(3.7825)\end{array}$ \\
\hline First-generation immigrant & $\begin{array}{c}-94.0122 * * * \\
(5.4507)\end{array}$ & $\begin{array}{c}-71.5323 * * * \\
(4.0654)\end{array}$ & $\begin{array}{c}-87.0751 * * * \\
(6.6967)\end{array}$ & $\begin{array}{c}-67.5016^{* * *} \\
(5.4076)\end{array}$ & $\begin{array}{c}-99.1185^{* * *} \\
(5.8971)\end{array}$ & $\begin{array}{c}-78.4737 * * * \\
(4.6487)\end{array}$ \\
\hline Schools fixed effects & & $\checkmark$ & & $\checkmark$ & & $\checkmark$ \\
\hline Observations & 7790 & 7790 & 4328 & 4328 & 4334 & 4334 \\
\hline Adjusted $\mathrm{R}^{2}$ & 0.1227 & 0.4552 & 0.1239 & 0.4217 & 0.1448 & 0.4879 \\
\hline
\end{tabular}

Source: PISA 2000 (national sample). Notes: dependant variables are test scores in reading literacy (columns 1 and 2), mathematics literacy (columns 3 and 4) and science literacy (columns 5 and 6). All observations are weighted with the students' weight. Clustered robust standard errors (at the school level) are in parentheses. *: significant at $10 \% ; * *$ : significant at $5 \% ; * * *$ : significant at $1 \%$. 


\section{Table 5}

The impact of immigration status on reading, mathematics and science literacy controlling for individual characteristics, family background and school characteristics

\begin{tabular}{|c|c|c|c|c|c|c|}
\hline \multirow[b]{2}{*}{ Swiss } & \multicolumn{2}{|c|}{ Reading } & \multicolumn{2}{|c|}{ Mathematics } & \multicolumn{2}{|c|}{ Science } \\
\hline & ref. & ref. & ref. & ref. & ref. & ref. \\
\hline Second-generation immigrant & $\begin{array}{c}-11.3316^{* * * *} \\
(4.0859)\end{array}$ & $\begin{array}{c}-13.9284 * * * \\
(3.5380)\end{array}$ & $\begin{array}{c}-21.4336 * * * \\
(5.2591)\end{array}$ & $\begin{array}{c}-23.7557 * * * \\
(5.2043)\end{array}$ & $\begin{array}{c}-21.3708 * * * \\
(5.0382)\end{array}$ & $\begin{array}{c}-24.8069 * * * \\
(4.6045)\end{array}$ \\
\hline First-generation immigrant & $\begin{array}{c}-22.8092 * * * \\
(4.4025)\end{array}$ & $\begin{array}{c}-22.5614 * * * \\
(3.9727)\end{array}$ & $\begin{array}{c}-27.7104 * * * \\
(5.6080)\end{array}$ & $\begin{array}{c}-27.0578 * * * \\
(5.5752)\end{array}$ & $\begin{array}{c}-32.5450 * * * \\
(6.5421)\end{array}$ & $\begin{array}{c}-35.6654 * * * \\
(6.1728)\end{array}$ \\
\hline Age (in months) & $\begin{array}{c}-1.5316 * * * \\
(0.1436)\end{array}$ & $\begin{array}{c}-1.4258 * * * \\
(0.1281)\end{array}$ & $\begin{array}{c}-1.7899 * * * \\
(0.1824)\end{array}$ & $\begin{array}{c}-1.7524 * * * \\
(0.1892)\end{array}$ & $\begin{array}{c}-1.2324 * * * \\
(0.1705)\end{array}$ & $\begin{array}{c}-1.0495 * * * \\
(0.1712)\end{array}$ \\
\hline Age is missing & $\begin{array}{c}-274.6493 * * * \\
(38.9099)\end{array}$ & $\begin{array}{c}-249.5347 * * * \\
(33.8792)\end{array}$ & $\begin{array}{c}-356.1357 * * * \\
(49.2102)\end{array}$ & $\begin{array}{c}-332.9416^{* * *} \\
(48.7099)\end{array}$ & $\begin{array}{c}-224.0846^{* * *} \\
(45.8309)\end{array}$ & $\begin{array}{c}-189.7976^{* * *} \\
(43.5251)\end{array}$ \\
\hline Female & $\begin{array}{c}16.8305 * * * \\
(2.0035)\end{array}$ & $\begin{array}{c}16.4136 * * * \\
(1.9362)\end{array}$ & $\begin{array}{c}-29.3079 * * * \\
(2.7345)\end{array}$ & $\begin{array}{c}-29.8505 * * * \\
(2.6351)\end{array}$ & $\begin{array}{c}-17.4529 * * * \\
(2.5739)\end{array}$ & $\begin{array}{c}-18.3305 * * * \\
(2.4481)\end{array}$ \\
\hline Language at home is the language of the test & $\begin{array}{c}22.1288 * * * \\
(3.2086)\end{array}$ & $\begin{array}{c}20.6555 * * * \\
(3.1759)\end{array}$ & $\begin{array}{c}23.4786 * * * \\
(4.4155)\end{array}$ & $\begin{array}{c}21.7745 * * * \\
(4.4384)\end{array}$ & $\begin{array}{c}20.7157 * * * \\
(4.4506)\end{array}$ & $\begin{array}{c}18.1737 * * * \\
(4.4637)\end{array}$ \\
\hline Language at home is missing & $\begin{array}{c}0.3806 \\
(7.0933)\end{array}$ & $\begin{array}{c}2.4977 \\
(6.2606)\end{array}$ & $\begin{array}{c}2.4785 \\
(8.5383)\end{array}$ & $\begin{array}{c}3.1206 \\
(8.7155)\end{array}$ & $\begin{array}{l}-8.1250 \\
(9.2980)\end{array}$ & $\begin{array}{l}-5.6351 \\
(8.6613)\end{array}$ \\
\hline Family structure is nuclear & $\begin{array}{c}8.3073 * * * \\
(2.5700)\end{array}$ & $\begin{array}{l}5.6389 * * \\
(2.4278)\end{array}$ & $\begin{array}{c}12.1801 * * * \\
(3.7139)\end{array}$ & $\begin{array}{l}9.7951 * * \\
(3.7966)\end{array}$ & $\begin{array}{c}13.0261 * * * \\
(3.2303)\end{array}$ & $\begin{array}{c}10.4717 * * * \\
(3.0639)\end{array}$ \\
\hline Family structure is missing & $\begin{array}{l}-23.2970 \\
(15.1642)\end{array}$ & $\begin{array}{c}-20.5621 \\
(12.4524)\end{array}$ & $\begin{array}{c}-13.6845 \\
(16.6100)\end{array}$ & $\begin{array}{l}-18.4160 \\
(14.1815)\end{array}$ & $\begin{array}{c}-5.9368 \\
(18.1234)\end{array}$ & $\begin{array}{c}-7.0874 \\
(22.8546)\end{array}$ \\
\hline Number of siblings & $\begin{array}{c}-6.1305 * * * \\
(1.0205)\end{array}$ & $\begin{array}{c}-4.9856 * * * \\
(0.8988)\end{array}$ & $\begin{array}{l}-3.2454 * * \\
(1.2500)\end{array}$ & $\begin{array}{l}-1.9191 \\
(1.2356)\end{array}$ & $\begin{array}{c}-3.1368 * * \\
(1.2950)\end{array}$ & $\begin{array}{l}-2.1184^{*} \\
(1.1258)\end{array}$ \\
\hline Number of siblings is missing & $\begin{array}{c}-9.7135 \\
(10.8588)\end{array}$ & $\begin{array}{r}-15.3499 \\
(9.5425)\end{array}$ & $\begin{array}{l}-13.1346 \\
(16.6778)\end{array}$ & $\begin{array}{l}-19.8109 \\
(15.5351)\end{array}$ & $\begin{array}{c}0.5091 \\
(17.8553)\end{array}$ & $\begin{array}{c}0.7184 \\
(15.6339)\end{array}$ \\
\hline Mother education: None or primary & ref. & ref. & ref. & ref. & ref. & ref. \\
\hline Lower secondary & $\begin{array}{c}13.8974 * * * \\
(5.3359)\end{array}$ & $\begin{array}{c}8.0927 \\
(4.9043)\end{array}$ & $\begin{array}{c}8.8774 \\
(7.2451)\end{array}$ & $\begin{array}{c}5.5545 \\
(7.6613)\end{array}$ & $\begin{array}{c}13.1515^{* *} \\
(5.8670)\end{array}$ & $\begin{array}{l}9.6755^{*} \\
(5.7138)\end{array}$ \\
\hline Vocational or prevocational upper-secondary & $\begin{array}{c}27.5455 * * * \\
(5.8644)\end{array}$ & $\begin{array}{c}19.9226 * * * \\
(5.3001)\end{array}$ & $\begin{array}{c}18.5076 * * * \\
(7.0833)\end{array}$ & $\begin{array}{c}14.2957 * * \\
(7.2478)\end{array}$ & $\begin{array}{c}27.7117 * * * \\
(6.9924)\end{array}$ & $\begin{array}{c}22.8306 * * * \\
(6.7237)\end{array}$ \\
\hline Upper secondary & $31.1749 * * *$ & $20.8872 * * *$ & $28.1653 * * *$ & $22.4056 * * *$ & $35.3448 * * *$ & $28.2941 * * *$ \\
\hline
\end{tabular}


Education level of mother is missing

Father education: None or primary

Lower secondary

Vocational or prevocational upper-secondary

Upper secondary

Education level of father is missing

\section{ISEI}

\section{ISEI is missing}

Number of books at home is 0-10

Number of books at home is $11-50$

Number of books at home is $51-100$

Number of books at home is $101-250$

Number of books at home is 251-500

Number of books at home is 501 or plus

Number of books at home is missing

\section{School size}

School size is missing

School/teacher ratio

\begin{tabular}{|c|c|c|c|c|c|}
\hline$(5.9514)$ & (4.9941) & (7.9781) & $(8.1760)$ & $(6.7828)$ & $(6.0851)$ \\
\hline 1.5332 & -0.5746 & 1.9756 & 7.2564 & 8.5524 & 9.1149 \\
\hline$(8.0331)$ & $(6.7288)$ & (10.2741) & (9.9029) & $(9.2920)$ & $(7.7266)$ \\
\hline ref. & ref. & ref. & ref. & ref. & ref. \\
\hline-2.2321 & 0.1105 & -6.6439 & -4.7247 & -6.6388 & -5.9231 \\
\hline$(4.5766)$ & $(4.3566)$ & $(5.8375)$ & $(5.4826)$ & $(5.9318)$ & $(5.6803)$ \\
\hline $10.4640 * *$ & $10.1981 * *$ & 3.0708 & 1.9797 & 9.2289 & 6.9318 \\
\hline$(5.0241)$ & $(4.8260)$ & $(6.0447)$ & $(5.9613)$ & $(6.6910)$ & $(6.3106)$ \\
\hline 5.9995 & 5.9843 & 4.0928 & 2.4523 & 1.1380 & -0.2223 \\
\hline$(5.5078)$ & (4.9930) & (7.4197) & $(7.0962)$ & (6.9299) & $(6.2375)$ \\
\hline-7.4956 & -2.6983 & -14.2453 & $-14.1963 *$ & -11.5378 & -8.3435 \\
\hline$(6.3553)$ & $(5.3990)$ & $(8.9151)$ & $(8.5310)$ & (8.5712) & (7.8172) \\
\hline $0.6580 * * *$ & $0.4222 * * *$ & $0.3423 * * *$ & $0.1480 *$ & $0.5263 * * *$ & $0.2644 * * *$ \\
\hline$(0.0690)$ & $(0.0628)$ & $(0.0924)$ & (0.0879) & $(0.0818)$ & $(0.0747)$ \\
\hline-2.9416 & -3.4624 & -16.5552 & -15.4649 & -1.9068 & -1.7639 \\
\hline (8.1613) & $(7.3661)$ & (10.7038) & (10.4229) & (10.6775) & $(9.5569)$ \\
\hline ref. & ref. & ref. & ref. & ref. & ref. \\
\hline $24.7418 * * *$ & $23.8740 * * *$ & $19.1394 * * *$ & $18.0674 * * *$ & $16.9292 * * *$ & $16.0618 * * *$ \\
\hline (3.9457) & $(3.8034)$ & $(5.2904)$ & $(4.7544)$ & $(5.3395)$ & $(5.3371)$ \\
\hline $32.9495 * * *$ & $28.6579 * * *$ & $21.9276 * * *$ & $20.3129 * * *$ & $29.7024 * * *$ & $24.2665 * * *$ \\
\hline$(4.2938)$ & $(3.7605)$ & $(5.1900)$ & $(4.6582)$ & $(5.4054)$ & $(5.2108)$ \\
\hline $46.3393 * * *$ & $38.1630 * * *$ & $41.5165 * * *$ & $32.6596 * * *$ & $45.8400 * * *$ & $37.0249 * * *$ \\
\hline$(4.2058)$ & (3.8706) & (5.3944) & $(4.8255)$ & $(5.4190)$ & $(5.4030)$ \\
\hline $55.1594 * * *$ & $48.1290 * * *$ & $42.1253 * * *$ & $35.7020 * * *$ & $53.2423 * * *$ & $45.1092 * * *$ \\
\hline$(4.3681)$ & (4.0164) & $(5.7115)$ & $(5.4120)$ & $(5.7360)$ & $(5.8429)$ \\
\hline $54.9908 * * *$ & $46.9865 * * *$ & $47.8011 * * *$ & $39.9571 * * *$ & $58.2899 * * *$ & $48.3689 * * *$ \\
\hline$(4.7309)$ & $(4.4921)$ & $(5.6873)$ & $(5.2782)$ & $(6.8546)$ & $(6.9154)$ \\
\hline 2.9250 & -2.8092 & $22.6288^{* *}$ & $15.5394 *$ & -1.8758 & -10.7803 \\
\hline (11.3798) & $(9.4402)$ & (10.0218) & $(8.5124)$ & (11.3851) & $(10.8766)$ \\
\hline $0.0284 * * *$ & & $0.0273 * * *$ & & $0.0369 * * *$ & \\
\hline$(0.0098)$ & & $(0.0098)$ & & $(0.0108)$ & \\
\hline 10.5836 & & 16.9410 & & 13.3961 & \\
\hline$(23.6090)$ & & $(22.3230)$ & & (24.0609) & \\
\hline$-2.0924 * * *$ & & $-2.0511 * * *$ & & $-2.0808 * *$ & \\
\hline$(0.6812)$ & & $(0.5967)$ & & $(0.8203)$ & \\
\hline
\end{tabular}


School/teacher ratio is missing

\section{Proportion of teachers ISCED 5}

Proportion of teachers ISCED 5 is missing

\section{School location is in a village}

Small town

Town

City

School location is missing

\section{Zurich}

Bern

Lucerne

Schwyz

Obwalden

Nidwalden

Glarus

Zug

Fribourg

Solothurn

Basel city
$-56.9261 * *$

(23.3123)

$77.4872 * * *$

(8.9368)

$50.0906 * * *$

(10.5301)

ref.

$-0.4727$

(7.0117)

3.8899

(8.3651)

0.2247

(9.0366)

0.3748

(17.9681)

ref.

$23.5777^{* * *}$

(8.3073)

8.9193

(15.0649)

42.4092*

(22.8311)

$60.3060 * * *$

(18.1926)

$142.3350 * * *$

(13.3862)

1.0287

(8.8322)

$57.8914 * *$

(23.2090)

8.8983

(11.4843)

23.6069

(16.4103)

15.7740
$-57.1118 * * *$

(20.9568)

$78.0114 * * *$

(8.4474)

48.8578***

(10.1028)

ref.

$-1.8466$

(6.8680)

0.6179

(8.3679)

$-2.1420$

(9.4915)

$-16.7636$

(19.0702)

ref.

12.6619

(7.9701)

$-1.0639$

(14.7156)

29.9460*

(17.1816)

$60.9220 * * *$

(18.0149)

$129.8638 * * *$

(14.7227)

$-29.9123 * * *$

(8.6412)

$46.2526^{* *}$

(23.0489)

11.2022

(11.7480)

14.8107

(17.8265)

6.9960

$$
\begin{gathered}
-56.4619 * * \\
(24.5764) \\
83.0961 * * * \\
(8.9754) \\
57.6706 * * \\
(11.0023) \\
\text { ref. } \\
-1.3717 \\
(7.1753) \\
3.0088 \\
(8.9151) \\
-6.4038 \\
(10.0190) \\
-6.4791 \\
(21.3530) \\
\text { ref. } \\
21.5475 * * \\
(8.5644) \\
2.4198 \\
(16.3110) \\
43.6407 * \\
(22.2231) \\
54.3041 * * * \\
(17.1489) \\
130.7862 * * \\
(14.3402) \\
-2.9952 \\
(9.7584) \\
51.4443 * \\
(27.9878) \\
22.1537 * \\
(12.0127) \\
26.2286 \\
(18.1369) \\
25.4200 \\
\end{gathered}
$$




\begin{tabular}{|c|c|c|c|c|c|c|}
\hline \multirow{3}{*}{ Basel county } & & \multicolumn{2}{|l|}{$(22.2885)$} & \multicolumn{2}{|l|}{$(19.8688)$} \\
\hline & 2.6401 & & -6.8493 & & 6.7156 & \\
\hline & $(9.4120)$ & & $(9.0127)$ & & $(9.8577)$ & \\
\hline Schaffhausen & $51.4751 * * *$ & & $77.3217 * * *$ & & $53.6601 * * *$ & \\
\hline & $(11.8271)$ & & $(10.9454)$ & & $(12.7745)$ & \\
\hline Appenzell outer rhodes & -1.6048 & & -1.1861 & & -12.4213 & \\
\hline & (10.2080) & & $(9.5826)$ & & (10.4228) & \\
\hline St Gallen & $\begin{array}{c}35.9640 * * * \\
(8.5705)\end{array}$ & & $\begin{array}{c}24.8551 * * * \\
(8.6226)\end{array}$ & & $\begin{array}{c}35.4441 * * * \\
(8.7044)\end{array}$ & \\
\hline Grisons & $\begin{array}{c}41.6036 * * * \\
(12.4248)\end{array}$ & & $\begin{array}{c}44.6258^{* * * *} \\
(11.8800)\end{array}$ & & $\begin{array}{c}52.1772 * * * \\
(13.1995)\end{array}$ & \\
\hline Aargau & $\begin{array}{c}44.7162 * * * \\
(11.6139)\end{array}$ & & $\begin{array}{c}38.2924 * * * \\
(10.6168)\end{array}$ & & $\begin{array}{c}49.4955^{* * *} \\
(11.5928)\end{array}$ & \\
\hline Thurgau & $\begin{array}{c}7.7734 \\
(19.9896)\end{array}$ & & $\begin{array}{c}18.7262 \\
(19.6733)\end{array}$ & & $\begin{array}{c}13.7022 \\
(19.8721)\end{array}$ & \\
\hline Ticino & $\begin{array}{c}31.4937 * * * \\
(9.4518)\end{array}$ & & $\begin{array}{c}1.2467 \\
(9.5930)\end{array}$ & & $\begin{array}{c}33.3541 * * * \\
(9.5408)\end{array}$ & \\
\hline Vaud & $\begin{array}{c}32.5165^{* * *} \\
(10.1770)\end{array}$ & & $\begin{array}{c}31.5676^{* * *} \\
(11.2152)\end{array}$ & & $\begin{array}{c}28.8880^{* *} \\
(12.2965)\end{array}$ & \\
\hline Valais & $\begin{array}{c}1.9433 \\
(10.6833)\end{array}$ & & $\begin{array}{l}-6.9880 \\
(9.8269)\end{array}$ & & $\begin{array}{c}5.2900 \\
(11.1604)\end{array}$ & \\
\hline Neuchatel & $\begin{array}{c}6.3374 \\
(10.6215)\end{array}$ & & $\begin{array}{c}-0.1211 \\
(10.2736)\end{array}$ & & $\begin{array}{l}10.9976 \\
(9.6452)\end{array}$ & \\
\hline Geneva & $\begin{array}{c}-36.9791 * * * \\
(9.5439)\end{array}$ & & $\begin{array}{c}-35.4849 * * * \\
(9.8618)\end{array}$ & & $\begin{array}{c}-29.5325^{* *} \\
(11.3834)\end{array}$ & \\
\hline Jura & $\begin{array}{l}-16.1041 \\
(9.7718)\end{array}$ & & $\begin{array}{l}-5.4600 \\
(9.3397)\end{array}$ & & $\begin{array}{l}-10.2616 \\
(11.4073)\end{array}$ & \\
\hline Schools fixed effects & & $\checkmark$ & & $\checkmark$ & & $\checkmark$ \\
\hline Constant & $\begin{array}{c}631.3751 * * * \\
(33.2577)\end{array}$ & $\begin{array}{c}684.1415^{* * *} \\
(26.3723)\end{array}$ & $\begin{array}{c}770.7256^{* * * *} \\
(38.8624)\end{array}$ & $\begin{array}{c}824.3298^{* * * *} \\
(38.0296)\end{array}$ & $\begin{array}{c}588.3293 * * * \\
(40.4823)\end{array}$ & $\begin{array}{c}636.8920 * * * \\
(37.4411)\end{array}$ \\
\hline Observations & 7790 & 7790 & 4328 & 4328 & 4334 & 4334 \\
\hline Adjusted $\mathrm{R}^{2}$ & 0.4479 & 0.5483 & 0.4251 & 0.5134 & 0.4681 & 0.5704 \\
\hline
\end{tabular}

Source: PISA 2000 (national sample). Notes: dependant variables are test scores in reading literacy (columns 1 and 2), mathematics literacy (columns 3 and 4) and science literacy (columns 5 and 6). All observations are weighted with the students' weight. Clustered robust standard errors (at the school level) are in parentheses. *: significant at $10 \%$; **: significant at $5 \% ; * * *$ : significant at $1 \%$. 


\section{Table 6}

The impact of immigration status on reading, mathematics and science literacy + interaction term (language x first-generation immigrant)

\begin{tabular}{|c|c|c|c|c|c|c|}
\hline \multirow{2}{*}{$\begin{array}{l}\text { Swiss } \\
\text { Second-generation immigrant }\end{array}$} & \multicolumn{2}{|c|}{ Reading } & \multicolumn{2}{|c|}{ Mathematics } & \multicolumn{2}{|c|}{ Science } \\
\hline & ref. & ref. & ref. & ref. & ref. & ref. \\
\hline Age (in months) & $\begin{array}{c}-1.5344 * * * \\
(0.1436)\end{array}$ & $\begin{array}{l}-1.4277 * * * \\
(0.1283)\end{array}$ & $\begin{array}{c}-1.7904 * * * \\
(0.1829)\end{array}$ & $\begin{array}{c}-1.7539 * * * \\
(0.1900)\end{array}$ & $\begin{array}{c}-1.2647^{* * *} \\
(0.1686)\end{array}$ & $\begin{array}{l}-1.0712 * * * \\
(0.1712)\end{array}$ \\
\hline Age is missing & $\begin{array}{l}-274.5918^{* * *} \\
(39.1597)\end{array}$ & $\begin{array}{l}-249.5191 * * * \\
(34.0851)\end{array}$ & $\begin{array}{l}-355.9064 * * * \\
(49.1250)\end{array}$ & $\begin{array}{l}-331.9995 * * * \\
(49.1283)\end{array}$ & $\begin{array}{l}-222.1290^{* * *} \\
(49.1291)\end{array}$ & $\begin{array}{l}-188.5385^{* * *} \\
(45.9665)\end{array}$ \\
\hline Language at home is the language of the test & $\begin{array}{c}23.1806^{* * * *} \\
(3.3006)\end{array}$ & $\begin{array}{c}21.3549^{* * * *} \\
(3.1521)\end{array}$ & $\begin{array}{c}24.0837 * * * \\
(4.7545)\end{array}$ & $\begin{array}{c}23.8938 * * * \\
(4.8003)\end{array}$ & $\begin{array}{l}25.7575^{* * * *} \\
(4.6587)\end{array}$ & $\begin{array}{c}21.5127 * * * \\
(4.5532)\end{array}$ \\
\hline Language at home is missing & $\begin{array}{l}0.8096 \\
(7.1376)\end{array}$ & $\begin{array}{l}2.7979 \\
(6.2531)\end{array}$ & $\begin{array}{l}2.7503 \\
(8.6369)\end{array}$ & $\begin{array}{l}4.1323 \\
(8.8664)\end{array}$ & $\begin{array}{l}-6.2111 \\
(9.4134)\end{array}$ & $\begin{array}{l}-4.4103 \\
(8.7279)\end{array}$ \\
\hline First-generation*language at home & $\begin{array}{l}-5.6330 \\
(8.4593)\end{array}$ & $\begin{array}{l}-3.6977 \\
(8.1215)\end{array}$ & $\begin{array}{c}-3.1136 \\
(12.4631)\end{array}$ & $\begin{array}{l}-10.6633 \\
(11.6215)\end{array}$ & $\begin{array}{c}-30.2028 * * * \\
(9.2324)\end{array}$ & $\begin{array}{l}-19.7705^{* *} \\
(8.9376)\end{array}$ \\
\hline Number of siblings & $\begin{array}{c}-6.1494 * * * \\
(1.0207)\end{array}$ & $\begin{array}{l}-4.9945 * * * \\
(0.8994)\end{array}$ & $\begin{array}{l}-3.2545^{* * *} \\
(1.2502)\end{array}$ & $\begin{array}{l}-1.9356 \\
(1.2326)\end{array}$ & $\begin{array}{c}-3.3131^{* *} \\
(1.2848)\end{array}$ & $\begin{array}{l}-2.2236^{* *} \\
(1.1197)\end{array}$ \\
\hline Number of siblings is missing & $\begin{array}{c}-9.6783 \\
(10.8621)\end{array}$ & $\begin{array}{l}-15.3287 \\
(9.5429)\end{array}$ & $\begin{array}{l}-13.1667 \\
(16.6964)\end{array}$ & $\begin{array}{l}-19.9820 \\
(15.5337)\end{array}$ & $\begin{array}{c}1.6490 \\
(17.6430)\end{array}$ & $\begin{array}{c}1.5804 \\
(15.4402)\end{array}$ \\
\hline Mother education: None or primary & ref. & ref. & ref. & ref. & ref. & ref. \\
\hline Lower secondary & $\begin{array}{l}14.1199 * * * \\
(5.3416)\end{array}$ & $\begin{array}{l}8.2302^{*} \\
(4.9186)\end{array}$ & $\begin{array}{l}9.0273 \\
(7.3833)\end{array}$ & $\begin{array}{c}6.0088 \\
(7.7971)\end{array}$ & $\begin{array}{c}14.1650 * * \\
(5.8238)\end{array}$ & $\begin{array}{l}10.2896^{*} \\
(5.7166)\end{array}$ \\
\hline Vocational or prevocational upper-secondary & $\begin{array}{l}27.7292 * * * \\
(5.8759)\end{array}$ & $\begin{array}{l}20.0402 * * * \\
(5.3116)\end{array}$ & $\begin{array}{c}18.6489 * * \\
(7.1822)\end{array}$ & $\begin{array}{c}14.7426^{* * *} \\
(7.3417)\end{array}$ & $\begin{array}{c}28.4504 * * * * \\
(6.9578)\end{array}$ & $\begin{array}{c}23.2875 * * * \\
(6.7124)\end{array}$ \\
\hline Upper secondary & $31.4348 * * *$ & $21.0537 * * *$ & $28.3400 * * *$ & $22.9457 * * *$ & $36.6218^{* * *}$ & $29.0901 * * *$ \\
\hline
\end{tabular}


Education level of mother is missing

Father education: None or primary

Lower secondary

Vocational or prevocational upper-secondary

Upper secondary

Education level of father is missing

\section{ISEI}

ISEI is missing

\section{Number of books at home is $\mathbf{0 - 1 0}$}

Number of books at home is $11-50$

Number of books at home is $51-100$

Number of books at home is $101-250$

Number of books at home is $251-500$

Number of books at home is 501 or plus

Number of books at home is missing

\section{School size}

School size is missing

\section{School/teacher ratio}

\begin{tabular}{|c|c|c|c|c|c|}
\hline (5.9719) & $(5.0060)$ & $(8.1210)$ & (8.3008) & $(6.8013)$ & $(6.1371)$ \\
\hline 1.8325 & -0.3804 & 2.1851 & 7.9296 & 10.0770 & 10.0746 \\
\hline$(8.0242)$ & (6.7239) & (10.2559) & (9.9139) & $(9.2457)$ & (7.7553) \\
\hline ref. & ref. & ref. & ref. & ref. & ref. \\
\hline-2.3350 & 0.0438 & -6.6932 & -4.8957 & -7.3441 & -6.3014 \\
\hline$(4.5781)$ & $(4.3544)$ & $(5.8795)$ & $(5.5014)$ & $(5.9080)$ & $(5.6495)$ \\
\hline $10.4016^{* *}$ & $10.1581 * *$ & 3.0346 & 1.8338 & 8.6854 & 6.6429 \\
\hline$(5.0231)$ & $(4.8252)$ & (6.0703) & $(5.9695)$ & $(6.6580)$ & $(6.2800)$ \\
\hline 5.9324 & 5.9427 & 4.0504 & 2.2982 & 0.5071 & -0.5465 \\
\hline$(5.5159)$ & (4.9949) & $(7.4618)$ & (7.1076) & $(6.8912)$ & $(6.2054)$ \\
\hline-7.6031 & -2.7690 & -14.2964 & $-14.3410 *$ & -12.5508 & -8.9383 \\
\hline$(6.3614)$ & $(5.4012)$ & (8.9148) & $(8.4560)$ & $(8.6157)$ & $(7.8596)$ \\
\hline $0.6596 * * *$ & $0.4231 * * *$ & $0.3432 * * *$ & $0.1509 *$ & $0.5315^{* * *}$ & $0.2676^{* * *}$ \\
\hline$(0.0689)$ & $(0.0627)$ & $(0.0928)$ & $(0.0880)$ & $(0.0816)$ & $(0.0745)$ \\
\hline-3.0340 & -3.5310 & -16.6174 & -15.6810 & -2.8078 & -2.4614 \\
\hline (8.1839) & (7.3902) & (10.6968) & $(10.4296)$ & (10.6074) & $(9.4718)$ \\
\hline ref. & ref. & ref. & ref. & ref. & ref. \\
\hline $24.7609 * * *$ & $23.8868 * * *$ & $19.1884 * * *$ & $18.2320 * * *$ & $17.2785^{* * * *}$ & $16.3301 * * *$ \\
\hline$(3.9434)$ & $(3.8024)$ & $(5.2837)$ & (4.7409) & $(5.2795)$ & $(5.2951)$ \\
\hline $32.9657 * * *$ & $28.6644 * * *$ & $21.9891 * * *$ & $20.5235 * * *$ & $30.0305 * * *$ & $24.4865 * * *$ \\
\hline$(4.2945)$ & $(3.7621)$ & $(5.2087)$ & (4.6889) & $(5.3579)$ & $(5.1850)$ \\
\hline $46.3938 * * *$ & $38.1992 * * *$ & $41.6026 * * *$ & $32.9480 * * *$ & $46.3568 * * *$ & $37.3996 * * *$ \\
\hline$(4.2031)$ & $(3.8730)$ & $(5.3880)$ & (4.8104) & $(5.3981)$ & $(5.3943)$ \\
\hline $55.2220 * * *$ & $48.1700 * * *$ & $42.2067 * * *$ & $35.9807 * * *$ & $53.8979 * * *$ & $45.5895 * * *$ \\
\hline$(4.3557)$ & $(4.0100)$ & $(5.7242)$ & $(5.4216)$ & $(5.6526)$ & $(5.8014)$ \\
\hline $55.0213 * * *$ & $47.0058 * * *$ & $47.8762 * * *$ & $40.2015 * * *$ & $58.7821 * * *$ & $48.7356 * * *$ \\
\hline$(4.7268)$ & $(4.4913)$ & $(5.6961)$ & $(5.2854)$ & $(6.8114)$ & $(6.8995)$ \\
\hline 2.8683 & -2.8504 & $22.6661 * *$ & $15.6053 *$ & -1.6147 & -10.5510 \\
\hline$(11.4076)$ & $(9.4656)$ & (10.0120) & $(8.5430)$ & (11.3454) & (10.8774) \\
\hline $0.0285 * * *$ & & $0.0273 * * *$ & & $0.0369 * * *$ & \\
\hline$(0.0098)$ & & $(0.0098)$ & & $(0.0108)$ & \\
\hline 10.7006 & & 16.9709 & & 13.9958 & \\
\hline$(23.5812)$ & & $(22.3251)$ & & $(23.9423)$ & \\
\hline$-2.0920 * * *$ & & $-2.0519 * * *$ & & $-2.0737 * *$ & \\
\hline$(0.6802)$ & & $(0.5969)$ & & $(0.8102)$ & \\
\hline
\end{tabular}


School/teacher ratio is missing

$-56.9368 * *$

(23.2929)

$77.4625^{* * *}$

(8.9381)

$50.0875^{* * *}$

(10.5226)

ref.

$-0.4595$

(7.0077)

3.9423

(8.3511)

0.2748

(9.0321)

0.3798

(17.9858)

ref.

Zurich

Bern

Lucerne

Schwyz

Obwalden

Nidwalden

Glarus

Zug

Fribourg

Solothurn

Basel city

$-57.0888^{* * *}$
$(20.9690)$
$78.0055^{* * *}$
$(8.4505)$
$48.8509 * * *$
$(10.1069)$
ref.
-1.8595
$(6.8693)$
0.6295
$(8.3591)$
-2.1286
$(9.4938)$
-16.7346
$(19.1056)$
ref.
12.6406
$(7.9720)$
-1.1099
$(14.7295)$
$29.9357 *$
$(17.1448)$
$60.9106 * * *$
$(18.0119)$
$129.7483^{* * *}$
$(14.6300)$
$-29.9754 * *$
$(8.6290)$
$46.3023^{* *}$
$(23.0510)$
11.2236
$(11.7427)$
14.8410
$(17.7959)$
6.9864

$-56.4568^{* *}$
$(24.4202)$
$82.7543^{* * *}$
$(8.9422)$
$57.4289^{* * *}$
$(10.8983)$
ref.
-1.2097
$(7.1382)$
3.3531
$(8.8573)$
-6.0778
$(9.9700)$
-6.4305
$(21.2353)$
ref.
$21.4470 * *$
$(8.5660)$
1.9556
$(16.3437)$
$43.4671 * *$
$(22.0387)$
$54.2126 * * *$
$(17.1465)$
$130.1225 * * *$
$(14.2896)$
-3.0242
$(9.7534)$
$52.0154 *$
$(28.1784)$
$22.2904 *$
$(11.8546)$
26.6471
$(17.8512)$
25.6341




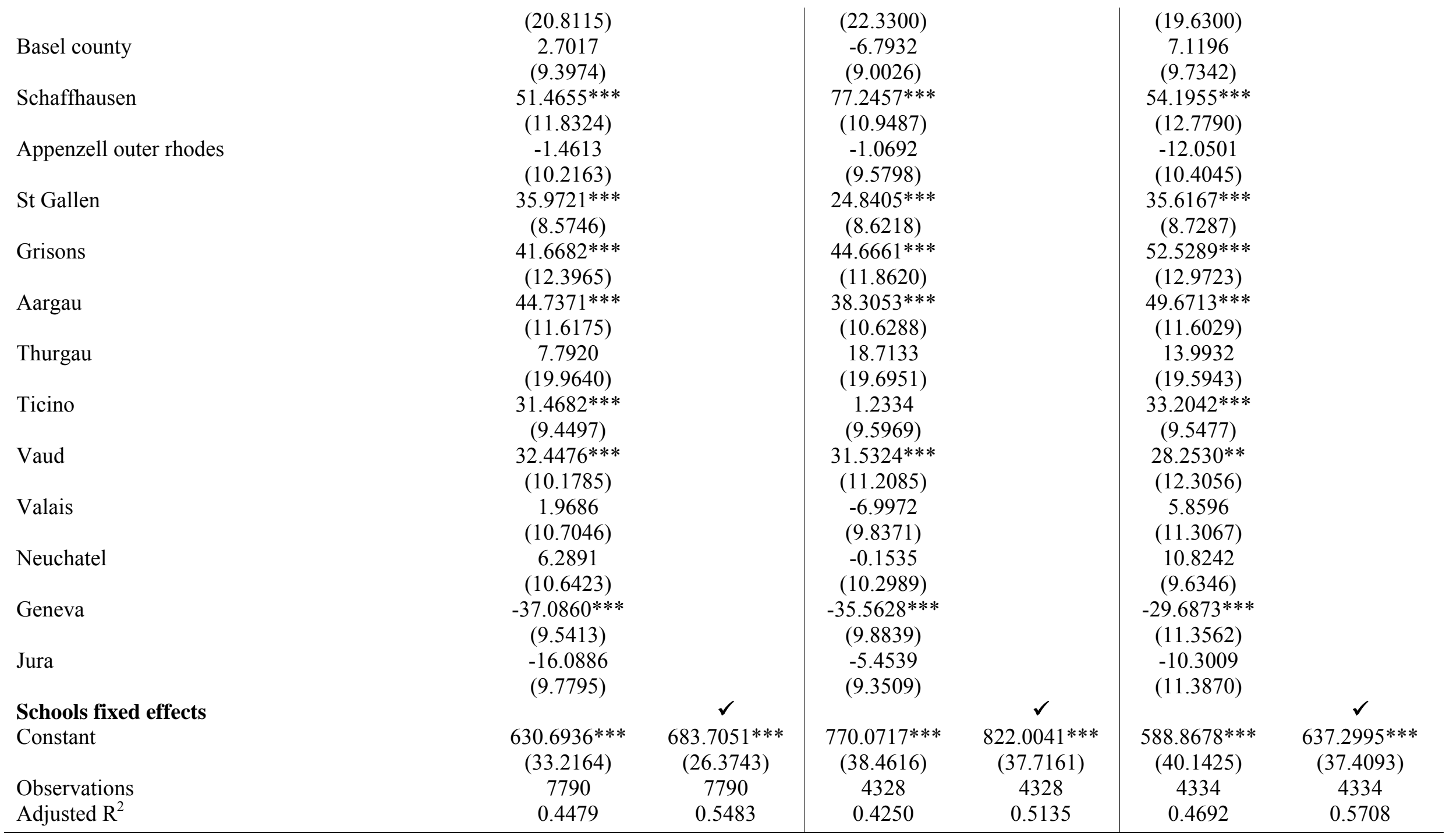

Source: PISA 2000 (national sample). Notes: dependant variables are test scores in reading literacy (columns 1 and 2), mathematics literacy (columns 3 and 4) and science literacy (columns 5 and 6). All observations are weighted with the students' weight. Clustered robust standard errors (at the school level) are in parentheses. *: significant at $10 \% ; *$ : significant at $5 \% ; * *$ : significant at $1 \%$. 
Table 7

The impact of immigration status on reading, mathematics and science literacy + Interaction term (language x second-generation immigrant)

\begin{tabular}{|c|c|c|c|c|c|c|}
\hline \multirow[b]{2}{*}{ Swiss } & \multicolumn{2}{|c|}{ Reading } & \multicolumn{2}{|c|}{ Mathematics } & \multicolumn{2}{|c|}{ Science } \\
\hline & ref. & ref. & ref. & ref. & ref. & ref. \\
\hline Age (in months) & $\begin{array}{c}-1.5299 * * * \\
(0.1434)\end{array}$ & $\begin{array}{c}-1.4283 * * * \\
(0.1284)\end{array}$ & $\begin{array}{c}-1.7914 * * * \\
(0.1827)\end{array}$ & $\begin{array}{c}-1.7548 * * * \\
(0.1894)\end{array}$ & $\begin{array}{c}-1.2312 * * * \\
(0.1704)\end{array}$ & $\begin{array}{c}-1.0514 * * * \\
(0.1718)\end{array}$ \\
\hline Age is missing & $\begin{array}{c}-274.0997 * * * \\
(38.9757)\end{array}$ & $\begin{array}{c}-250.3618 * * * \\
(34.2387)\end{array}$ & $\begin{array}{c}-356.9340 * * * \\
(49.7809)\end{array}$ & $\begin{array}{c}-334.3319 * * * \\
(49.6436)\end{array}$ & $\begin{array}{c}-223.9484 * * * \\
(45.8589)\end{array}$ & $\begin{array}{c}-189.9464 * * * \\
(43.6960)\end{array}$ \\
\hline Language at home is the language of the test & $\begin{array}{c}22.7431 * * * \\
(3.6424)\end{array}$ & $\begin{array}{c}19.6233^{* * * *} \\
(3.5285)\end{array}$ & $\begin{array}{c}21.8539 * * * \\
(5.1020)\end{array}$ & $\begin{array}{c}18.1694 * * * \\
(5.0299)\end{array}$ & $\begin{array}{c}21.0537^{* * * *} \\
(4.9525)\end{array}$ & $\begin{array}{c}17.6277^{* * * *} \\
(4.9298)\end{array}$ \\
\hline Language at home is missing & $\begin{array}{c}0.5494 \\
(7.2180)\end{array}$ & $\begin{array}{c}2.2183 \\
(6.3072)\end{array}$ & $\begin{array}{c}2.2077 \\
(8.5288)\end{array}$ & $\begin{array}{c}2.6448 \\
(8.6713)\end{array}$ & $\begin{array}{l}-8.0076 \\
(9.3746)\end{array}$ & $\begin{array}{c}-5.8244 \\
(8.6744)\end{array}$ \\
\hline Second-generation*language at home & $\begin{array}{c}-2.5802 \\
(7.4757)\end{array}$ & $\begin{array}{c}4.3002 \\
(7.0484)\end{array}$ & $\begin{array}{c}7.3595 \\
(\mathbf{1 0 . 6 6 4 7 )}\end{array}$ & $\begin{array}{c}16.1972 \\
(10.8958)\end{array}$ & $\begin{array}{l}-1.3550 \\
(9.2920)\end{array}$ & $\begin{array}{c}2.1718 \\
(8.8445)\end{array}$ \\
\hline Number of siblings & $\begin{array}{c}-6.1292 * * * \\
(1.0201)\end{array}$ & $\begin{array}{c}-4.9884 * * * \\
(0.8981)\end{array}$ & $\begin{array}{c}-3.2366^{* *} \\
(1.2499)\end{array}$ & $\begin{array}{l}-1.9001 \\
(1.2330)\end{array}$ & $\begin{array}{c}-3.1341^{* *} \\
(1.2948)\end{array}$ & $\begin{array}{l}-2.1242 * \\
(1.1250)\end{array}$ \\
\hline Number of siblings is missing & $\begin{array}{c}-9.7539 \\
(10.8547)\end{array}$ & $\begin{array}{l}-15.2554 \\
(9.5310)\end{array}$ & $\begin{array}{l}-12.8739 \\
(16.6215)\end{array}$ & $\begin{array}{l}-19.0296 \\
(15.3851)\end{array}$ & $\begin{array}{c}0.5125 \\
(17.8513)\end{array}$ & $\begin{array}{c}0.7234 \\
(15.6400)\end{array}$ \\
\hline Mother education: None or primary & ref. & ref. & ref. & ref. & ref. & ref. \\
\hline Lower secondary & $\begin{array}{c}13.9031^{* * *} \\
(5.3464)\end{array}$ & $\begin{array}{c}8.0691 \\
(4.8874)\end{array}$ & $\begin{array}{c}8.9373 \\
(7.2226)\end{array}$ & $\begin{array}{c}5.6521 \\
(7.5679)\end{array}$ & $\begin{array}{c}13.1563 * * \\
(5.8776)\end{array}$ & $\begin{array}{l}9.6688^{*} \\
(5.7081)\end{array}$ \\
\hline Vocational or prevocational upper-secondary & $\begin{array}{c}27.5710^{* * * *} \\
(5.8824)\end{array}$ & $\begin{array}{c}19.8705^{* * *} * \\
(5.2923)\end{array}$ & $\begin{array}{c}18.5443 * * * \\
(7.0541)\end{array}$ & $\begin{array}{c}14.3303^{* *} \\
(7.1435)\end{array}$ & $\begin{array}{c}27.7189 * * * \\
(7.0067)\end{array}$ & $\begin{array}{c}22.8175^{* * *} \\
(6.7234)\end{array}$ \\
\hline Upper secondary & $31.1831 * * *$ & $20.8579 * * *$ & $28.2857 * * *$ & $22.6401 * * *$ & $35.3387 * * *$ & $28.2972 * * *$ \\
\hline
\end{tabular}


Education level of mother is missing

Father education: None or primary

Lower secondary

Vocational or prevocational upper-secondary

Upper secondary

Education level of father is missing

\section{ISEI}

ISEI is missing

\section{Number of books at home is $\mathbf{0 - 1 0}$}

Number of books at home is $11-50$

Number of books at home is $51-100$

Number of books at home is $101-250$

Number of books at home is $251-500$

Number of books at home is 501 or plus

Number of books at home is missing

\section{School size}

School size is missing

\section{School/teacher ratio}

\begin{tabular}{|c|c|c|c|c|c|}
\hline$(5.9615)$ & $(4.9818)$ & $(7.9856)$ & $(8.1223)$ & $(6.7801)$ & $(6.0773)$ \\
\hline 1.5790 & -0.6690 & 1.8448 & 6.9413 & 8.5494 & 9.1091 \\
\hline$(8.0525)$ & $(6.7226)$ & (10.2367) & $(9.7965)$ & (9.2910) & (7.7242) \\
\hline ref. & ref. & ref. & ref. & ref. & ref. \\
\hline-2.1944 & 0.0619 & -6.7080 & -4.8366 & -6.6305 & -5.9295 \\
\hline$(4.5698)$ & $(4.3538)$ & $(5.8428)$ & $(5.5094)$ & $(5.9328)$ & $(5.6834)$ \\
\hline $10.4804 * *$ & $10.1838 * *$ & 3.0353 & 1.9314 & 9.2355 & 6.9269 \\
\hline$(5.0271)$ & $(4.8235)$ & $(6.0343)$ & $(5.9482)$ & (6.6929) & $(6.3162)$ \\
\hline 6.0274 & 5.9531 & 3.9857 & 2.2360 & 1.1540 & -0.2359 \\
\hline$(5.5033)$ & (4.9968) & $(7.4130)$ & (7.0923) & $(6.9257)$ & $(6.2451)$ \\
\hline-7.4948 & -2.6830 & -14.0652 & -13.7798 & -11.5198 & -8.3595 \\
\hline$(6.3556)$ & $(5.3955)$ & $(8.9636)$ & $(8.5845)$ & $(8.5714)$ & $(7.8272)$ \\
\hline $0.6581 * * *$ & $0.4222 * * *$ & $0.3415 * * *$ & $0.1469 *$ & $0.5264 * * *$ & $0.2641 * * *$ \\
\hline$(0.0690)$ & $(0.0628)$ & $(0.0926)$ & $(0.0878)$ & $(0.0818)$ & $(0.0748)$ \\
\hline-2.8962 & -3.5382 & -16.7987 & -15.9671 & -1.8947 & -1.7838 \\
\hline$(8.1710)$ & (7.3609) & (10.7173) & (10.4107) & (10.6742) & $(9.5401)$ \\
\hline ref. & ref. & ref. & ref. & ref. & ref. \\
\hline $24.7463 * * *$ & $23.8745 * * *$ & $19.1372 * * *$ & $18.1160 * * *$ & $16.9217 * * *$ & $16.0781 * * *$ \\
\hline$(3.9466)$ & $(3.8031)$ & $(5.2980)$ & (4.7714) & $(5.3382)$ & $(5.3215)$ \\
\hline $32.9590 * * *$ & $28.6440 * * *$ & $21.8850 * * *$ & $20.2675 * * *$ & $29.6936 * * *$ & $24.2828 * * *$ \\
\hline$(4.2967)$ & $(3.7647)$ & $(5.2007)$ & $(4.6790)$ & $(5.4023)$ & $(5.1979)$ \\
\hline $46.3482 * * *$ & $38.1570 * * *$ & $41.4958 * * *$ & $32.6548 * * *$ & $45.8394 * * *$ & $37.0311 * * *$ \\
\hline$(4.2062)$ & $(3.8734)$ & $(5.3993)$ & $(4.8351)$ & $(5.4195)$ & (5.3990) \\
\hline $55.1638 * * *$ & $48.1260 * * *$ & $42.1708 * * *$ & $35.8382 * * *$ & $53.2439 * * *$ & $45.1114 * * *$ \\
\hline$(4.3706)$ & $(4.0132)$ & $(5.6943)$ & $(5.3815)$ & $(5.7397)$ & $(5.8364)$ \\
\hline $55.0385 * * *$ & $46.9135 * * *$ & $47.6884 * * *$ & $39.7097 * * *$ & $58.3019 * * *$ & $48.3555 * * *$ \\
\hline$(4.7313)$ & $(4.4988)$ & $(5.7117)$ & $(5.3117)$ & $(6.8591)$ & $(6.9229)$ \\
\hline 2.9902 & -2.9176 & $22.4988 * *$ & $15.2230 *$ & -1.8638 & -10.8135 \\
\hline (11.3779) & $(9.4267)$ & (10.0478) & $(8.5513)$ & (11.3901) & $(10.8550)$ \\
\hline $0.0284 * * *$ & & $0.0273 * * *$ & & $0.0369 * * *$ & \\
\hline$(0.0098)$ & & $(0.0098)$ & & $(0.0108)$ & \\
\hline 10.6464 & & 16.8130 & & 13.4418 & \\
\hline$(23.5572)$ & & $(22.4815)$ & & $(24.0670)$ & \\
\hline$-2.0931 * * *$ & & $-2.0482 * * *$ & & $-2.0815 * *$ & \\
\hline$(0.6808)$ & & $(0.5977)$ & & $(0.8201)$ & \\
\hline
\end{tabular}


School/teacher ratio is missing

\section{Proportion of teachers ISCED 5}

Proportion of teachers ISCED 5 is missing

\section{School location is in a village}

Small town

Town

City

School location is missing

\section{Zurich}

Bern

Lucerne

Schwyz

Obwalden

Nidwalden

Glarus

Zug

Fribourg

Solothurn

Basel city

$-57.0148 * *$
$(23.2683)$
$77.5045 * *$
$(8.9312)$
$50.1485 * * *$
$(10.5352)$
ref.
-0.4685
$(7.0072)$
3.9065
$(8.3599)$
0.2126
$(9.0285)$
0.3418
$(17.9709)$
ref.
$23.6107 * * *$
$(8.3035)$
8.8812
$(15.0727)$
$42.3868 *$
$(22.8312)$
$60.3050 * * *$
$(18.1880)$
$142.3446 * *$
$(13.3780)$
1.0804
$(8.8312)$
$57.8136 * *$
$(23.1812)$
8.9115
$(11.4799)$
23.5973
$(16.4065)$
15.7572

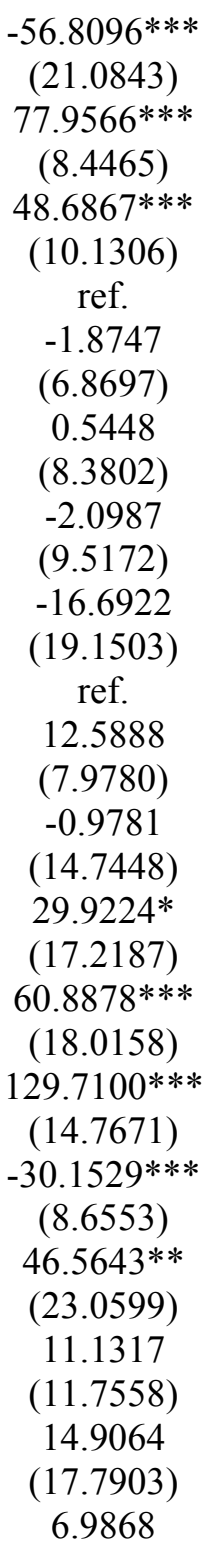




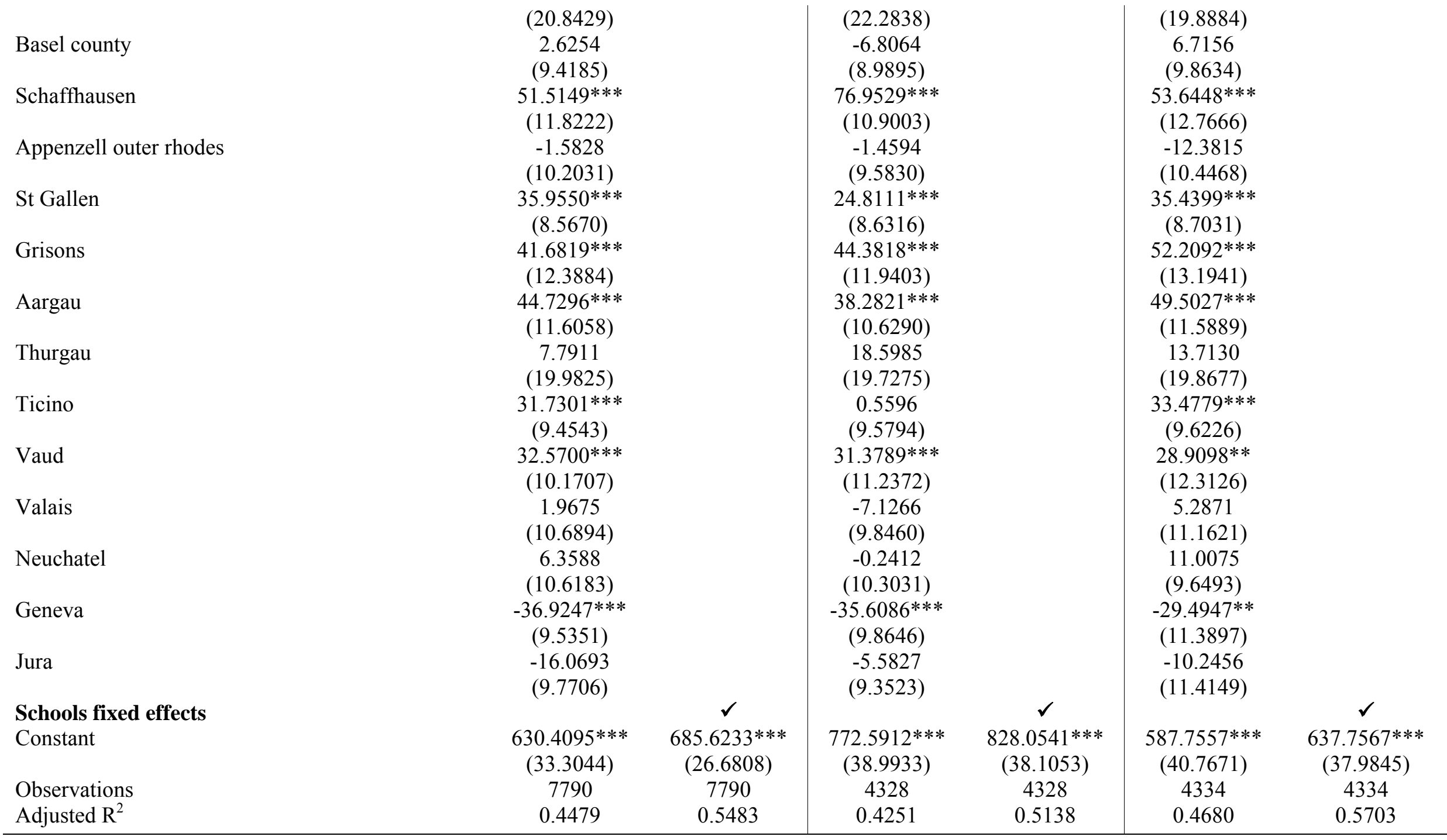

Source: PISA 2000 (national sample). Notes: dependant variables are test scores in reading literacy (columns 1 and 2), mathematics literacy (columns 3 and 4 ) and science literacy (columns 5 and 6). All observations are weighted with the students' weight. Clustered robust standard errors (at the school level) are in parentheses. *: significant at $10 \% ; *$ : significant at $5 \% ; * *$ : significant at $1 \%$. 


\section{Table 8}

The impact of immigration status on reading, mathematics and science literacy + interaction term (number of siblings $\mathrm{x}$ first-generation immigrant)

\begin{tabular}{|c|c|c|c|c|c|c|}
\hline \multirow[b]{2}{*}{ Swiss } & \multicolumn{2}{|c|}{ Reading } & \multicolumn{2}{|c|}{ Mathematics } & \multicolumn{2}{|c|}{ Science } \\
\hline & ref. & ref. & ref. & ref. & ref. & ref. \\
\hline Second-generation immigrant & $\begin{array}{c}-11.6052 * * * \\
(4.0554)\end{array}$ & $\begin{array}{c}-14.1720 * * * \\
(3.5142)\end{array}$ & $\begin{array}{c}-21.8408 * * * \\
(5.2286)\end{array}$ & $\begin{array}{c}-24.2090 * * * \\
(5.1821)\end{array}$ & $\begin{array}{c}-21.6698 * * * \\
(5.0402)\end{array}$ & $\begin{array}{c}-24.9582 * * * \\
(4.6053)\end{array}$ \\
\hline First-generation immigrant & $\begin{array}{l}-8.1745 \\
(5.8527)\end{array}$ & $\begin{array}{c}-10.2731 * \\
(5.2592)\end{array}$ & $\begin{array}{r}-11.3735 \\
(7.2463)\end{array}$ & $\begin{array}{r}-10.9392 \\
(7.3703)\end{array}$ & $\begin{array}{c}-24.4910 * * * \\
(8.5398)\end{array}$ & $\begin{array}{c}-31.4867 * * * \\
(7.6315)\end{array}$ \\
\hline Age (in months) & $\begin{array}{c}-1.5006 * * * \\
(0.1433)\end{array}$ & $\begin{array}{c}-1.4020 * * * \\
(0.1278)\end{array}$ & $\begin{array}{c}-1.7564 * * * \\
(0.1837)\end{array}$ & $\begin{array}{c}-1.7239 * * * \\
(0.1900)\end{array}$ & $\begin{array}{c}-1.2166^{* * *} \\
(0.1700)\end{array}$ & $\begin{array}{c}-1.0424 * * * \\
(0.1716)\end{array}$ \\
\hline Age is missing & $\begin{array}{c}-270.4995^{* * *} \\
(38.8238)\end{array}$ & $\begin{array}{c}-246.4910^{* * *} \\
(33.8135)\end{array}$ & $\begin{array}{c}-352.2032 * * * \\
(48.9322)\end{array}$ & $\begin{array}{c}-329.6419 * * * \\
(48.4769)\end{array}$ & $\begin{array}{c}-222.7487^{* * *} * \\
(45.3221)\end{array}$ & $\begin{array}{c}-189.4545^{* * * *} \\
\quad(43.3405)\end{array}$ \\
\hline Female & $\begin{array}{c}17.0516^{* * *} \\
(2.0098)\end{array}$ & $\begin{array}{c}16.6042 * * * \\
(1.9472)\end{array}$ & $\begin{array}{c}-29.0750 * * * \\
(2.7233)\end{array}$ & $\begin{array}{c}-29.6112 * * * \\
(2.6333)\end{array}$ & $\begin{array}{c}-17.2476 * * * \\
(2.5818)\end{array}$ & $\begin{array}{c}-18.2201 * * * \\
\quad(2.4584)\end{array}$ \\
\hline Language at home is the language of the test & $\begin{array}{c}21.7951 * * * \\
\quad(3.2186)\end{array}$ & $\begin{array}{c}20.4042 * * * \\
\quad(3.1966)\end{array}$ & $\begin{array}{c}23.2792 * * * \\
\quad(4.3698)\end{array}$ & $\begin{array}{c}21.6718 * * * \\
(4.4071)\end{array}$ & $\begin{array}{c}20.3208 * * * \\
(4.4917)\end{array}$ & $\begin{array}{c}18.0051 * * * \\
(4.5219)\end{array}$ \\
\hline Language at home is missing & $\begin{array}{l}-0.0595 \\
(7.0292)\end{array}$ & $\begin{array}{c}2.2804 \\
(6.2361)\end{array}$ & $\begin{array}{c}2.4950 \\
(8.4645)\end{array}$ & $\begin{array}{c}3.2794 \\
(8.6565)\end{array}$ & $\begin{array}{l}-8.6771 \\
(9.1615)\end{array}$ & $\begin{array}{l}-5.8162 \\
(8.6301)\end{array}$ \\
\hline Family structure is nuclear & $\begin{array}{c}8.3430 * * * \\
(2.5612)\end{array}$ & $\begin{array}{l}5.6490 * * \\
(2.4218)\end{array}$ & $\begin{array}{c}12.1018 * * * \\
(3.7097)\end{array}$ & $\begin{array}{l}9.7153 * * \\
(3.7854)\end{array}$ & $\begin{array}{c}13.0977 * * * \\
(3.2151)\end{array}$ & $\begin{array}{c}10.4960 * * * \\
(3.0562)\end{array}$ \\
\hline Family structure is missing & $\begin{array}{l}-23.2638 \\
(15.1020)\end{array}$ & $\begin{array}{l}-20.7168 * \\
(12.3943)\end{array}$ & $\begin{array}{c}-13.7569 \\
(16.6879)\end{array}$ & $\begin{array}{l}-18.5527 \\
(14.2722)\end{array}$ & $\begin{array}{c}-5.8493 \\
(17.9182)\end{array}$ & $\begin{array}{c}-7.1183 \\
(22.7397)\end{array}$ \\
\hline Number of siblings & $\begin{array}{c}-4.6930 * * * \\
(1.0489)\end{array}$ & $\begin{array}{c}-3.7657 * * * \\
(0.9308)\end{array}$ & $\begin{array}{l}-1.7536 \\
(1.2611)\end{array}$ & $\begin{array}{l}-0.4007 \\
(1.2789)\end{array}$ & $\begin{array}{l}-2.2808 \\
(1.3835)\end{array}$ & $\begin{array}{l}-1.6668 \\
(1.2570)\end{array}$ \\
\hline Number of siblings is missing & $\begin{array}{c}-10.2700 \\
(10.9014)\end{array}$ & $\begin{array}{c}-15.8846^{*} \\
(9.5324)\end{array}$ & $\begin{array}{l}-12.5962 \\
(16.6590)\end{array}$ & $\begin{array}{l}-19.3726 \\
(15.4926)\end{array}$ & $\begin{array}{c}-0.0106 \\
(18.0819)\end{array}$ & $\begin{array}{c}0.4021 \\
(15.7107)\end{array}$ \\
\hline $\begin{array}{l}\text { First-generation*number of siblings } \\
\text { Mother education: None or primary }\end{array}$ & $\begin{array}{l}-8.1225 * * * \\
(2.6910) \\
\text { ref. }\end{array}$ & $\begin{array}{l}-6.8528 * * * \\
(2.0470) \\
\text { ref. }\end{array}$ & $\begin{array}{l}-9.0146 * * * \\
(3.0053) \\
\text { ref. }\end{array}$ & $\begin{array}{l}-8.9839 * * * \\
(2.7833) \\
\text { ref. }\end{array}$ & $\begin{array}{l}-4.5314 \\
(3.7013) \\
\text { ref. }\end{array}$ & $\begin{array}{l}-2.3562 \\
(2.8613) \\
\text { ref. }\end{array}$ \\
\hline Lower secondary & $\begin{array}{c}12.4682 * * \\
(5.5411)\end{array}$ & $\begin{array}{c}6.9232 \\
(5.0707)\end{array}$ & $\begin{array}{c}6.7469 \\
(7.4700)\end{array}$ & $\begin{array}{c}3.5260 \\
(7.7359)\end{array}$ & $\begin{array}{c}12.4499 * * \\
(5.8900)\end{array}$ & $\begin{array}{c}9.3311 \\
(5.7148)\end{array}$ \\
\hline Vocational or prevocational upper-secondary & $\begin{array}{c}26.1212 * * * \\
(6.0330)\end{array}$ & $\begin{array}{c}18.7389 * * * \\
(5.4193)\end{array}$ & $\begin{array}{c}16.3922 * * \\
(7.3275)\end{array}$ & $\begin{array}{l}12.1951 * \\
(7.3183)\end{array}$ & $\begin{array}{c}27.0565 * * * \\
(7.0139)\end{array}$ & $\begin{array}{c}22.5082 * * * \\
(6.7354)\end{array}$ \\
\hline Upper secondary & $29.5081 * * *$ & $19.5202 * * *$ & $25.8207 * * *$ & $20.1098 * *$ & $34.5754 * * *$ & $27.9345 * * *$ \\
\hline
\end{tabular}


Education level of mother is missing

Father education: None or primary

Lower secondary

Vocational or prevocational upper-secondary

Upper secondary

Education level of father is missing

\section{ISEI}

ISEI is missing

\section{Number of books at home is $\mathbf{0 - 1 0}$}

Number of books at home is $11-50$

Number of books at home is $51-100$

Number of books at home is $101-250$

Number of books at home is $251-500$

Number of books at home is 501 or plus

Number of books at home is missing

\section{School size}

School size is missing

\section{School/teacher ratio}

\begin{tabular}{|c|c|c|c|c|c|}
\hline$(6.0924)$ & $(5.0925)$ & $(8.1873)$ & $(8.2280)$ & $(6.7460)$ & $(6.0816)$ \\
\hline 0.4576 & -1.4510 & 0.1101 & 5.5067 & 7.9101 & 8.7932 \\
\hline$(8.1578)$ & (6.8194) & (10.4249) & (10.0096) & $(9.2971)$ & $(7.7345)$ \\
\hline ref. & ref. & ref. & ref. & ref. & ref. \\
\hline-0.9631 & 1.1515 & -5.1957 & -3.2547 & -5.8006 & -5.4982 \\
\hline$(4.7053)$ & $(4.4421)$ & $(5.6835)$ & (5.1794) & $(6.0513)$ & $(5.7579)$ \\
\hline $11.7849 * *$ & $11.3033 * *$ & 4.5625 & 3.4623 & 10.0540 & 7.3773 \\
\hline$(5.0761)$ & (4.8469) & (5.9191) & (5.7099) & $(6.7795)$ & $(6.3884)$ \\
\hline 7.5199 & 7.2828 & 5.7071 & 4.0895 & 2.0712 & 0.2738 \\
\hline$(5.5746)$ & (4.9949) & $(7.3352)$ & $(6.9050)$ & (6.9989) & $(6.2642)$ \\
\hline-6.1879 & -1.6388 & -12.5521 & -12.4984 & -10.5480 & -7.8595 \\
\hline (6.3108) & $(5.3724)$ & $(8.7637)$ & $(8.3810)$ & $(8.5163)$ & $(7.8507)$ \\
\hline $0.6569 * * *$ & $0.4209 * * *$ & $0.3400 * * *$ & 0.1447 & $0.5264 * * *$ & $0.2645 * * *$ \\
\hline$(0.0688)$ & $(0.0626)$ & $(0.0920)$ & $(0.0877)$ & $(0.0818)$ & $(0.0748)$ \\
\hline-1.7175 & -2.4379 & -15.8813 & -14.9450 & -1.0339 & -1.3096 \\
\hline$(8.1895)$ & (7.3929) & (10.7646) & $(10.5326)$ & (10.7309) & (9.5177) \\
\hline ref. & ref. & ref. & ref. & ref. & ref. \\
\hline $24.9079 * * *$ & $23.9928 * * *$ & $19.5199 * * *$ & $18.3270 * * *$ & $16.9595 * * *$ & $16.0705 * * *$ \\
\hline$(3.9650)$ & $(3.8165)$ & $(5.2696)$ & (4.6976) & $(5.3579)$ & $(5.3462)$ \\
\hline $33.1798 * * *$ & $28.7929 * * *$ & $22.0262 * * *$ & $20.2598 * * *$ & $29.6747 * * *$ & $24.2287 * * *$ \\
\hline$(4.3302)$ & $(3.7956)$ & $(5.1966)$ & $(4.6518)$ & $(5.4516)$ & $(5.2348)$ \\
\hline $46.4006 * * *$ & $38.2061 * * *$ & $41.6453 * * *$ & $32.6429 * * *$ & $45.7100 * * *$ & $36.9557 * * *$ \\
\hline$(4.2597)$ & $(3.9028)$ & $(5.4249)$ & $(4.8279)$ & $(5.4678)$ & $(5.4232)$ \\
\hline $55.1677 * * *$ & $48.1338 * * *$ & $42.1762 * * *$ & $35.6690 * * *$ & $53.1068 * * *$ & $45.0314 * * *$ \\
\hline$(4.4040)$ & $(4.0451)$ & $(5.7406)$ & $(5.4398)$ & $(5.7677)$ & $(5.8548)$ \\
\hline $54.8056^{* * *}$ & $46.8206 * * *$ & $47.6055 * * *$ & $39.6656 * * *$ & $57.9847 * * *$ & $48.2014 * * *$ \\
\hline$(4.7522)$ & $(4.4852)$ & $(5.6980)$ & $(5.2768)$ & (6.9128) & $(6.9227)$ \\
\hline 3.8956 & -2.0787 & $23.2456 * *$ & $16.0593 *$ & -1.8352 & -10.8368 \\
\hline (11.2332) & $(9.3402)$ & $(9.9424)$ & $(8.4086)$ & (11.5429) & (10.9340) \\
\hline $0.0286 * * *$ & & $0.0275 * * *$ & & $0.0368 * * *$ & \\
\hline$(0.0098)$ & & $(0.0098)$ & & $(0.0108)$ & \\
\hline 10.7369 & & 16.7309 & & 13.6068 & \\
\hline$(23.5724)$ & & $(22.3411)$ & & $(24.0346)$ & \\
\hline$-2.1001 * * *$ & & $-2.0508 * * *$ & & $-2.0861 * *$ & \\
\hline$(0.6794)$ & & $(0.5962)$ & & $(0.8181)$ & \\
\hline
\end{tabular}


School/teacher ratio is missing

$-57.1299 * *$

(23.2890)

$77.4175 * * *$

(8.9166)

$50.1433 * * *$

(10.5108)

ref.

$-0.1900$

(6.9997)

4.0049

(8.3493)

0.3058

(9.0132)

0.1477

(18.1171)

ref.

23.4630 ***

(8.3032)

8.3728

(15.0466)

42.0594*

(22.6994)

$59.1756^{* * *}$

(18.4496)

$141.6904 * * *$

(13.3648)

0.5520

(8.8247)

$57.6338 * *$

(23.0723)

8.3946

(11.4466)

23.4602

(16.2729)

15.8015
$-57.3910 * * *$

(21.0042)

$77.9522 * * *$

(8.4333)

$48.9831 * * *$

(10.1246)

ref.

$-1.4460$

(6.8631)

0.6934

(8.3842)

$-1.9152$

(9.4749)

$-16.3342$

(19.3946)

ref.

12.6227

(7.9474)

$-2.1531$

(14.8532)

29.3467*

(17.0807)

$59.1977 * * *$

(18.3568)

$129.8985^{* * *}$

(14.7434)

$-29.5139 * * *$

(8.6303)

46.1181**

(22.8282)

10.8112

(11.6559)

14.8141

(17.4399)

6.8774

$-56.5394 * *$
$(24.5436)$
$82.9987 * *$
$(8.9561)$
$57.7065 * *$
$(11.0181)$
ref.
-1.1472
$(7.1531)$
3.2092
$(8.8854)$
-6.3232
$(9.9855)$
-6.7815
$(21.4239)$
ref.
$21.5278 * *$
$(8.5497)$
2.4969
$(16.2918)$
$43.4416 *$
$(22.1371)$
$53.7426 * *$
$(17.2698)$
$130.2252 * *$
$(14.3480)$
-3.3327
$(9.7220)$
$51.4385 *$
$(27.9440)$
$21.9592 *$
$(12.0380)$
26.2514
$(17.9975)$
25.8733




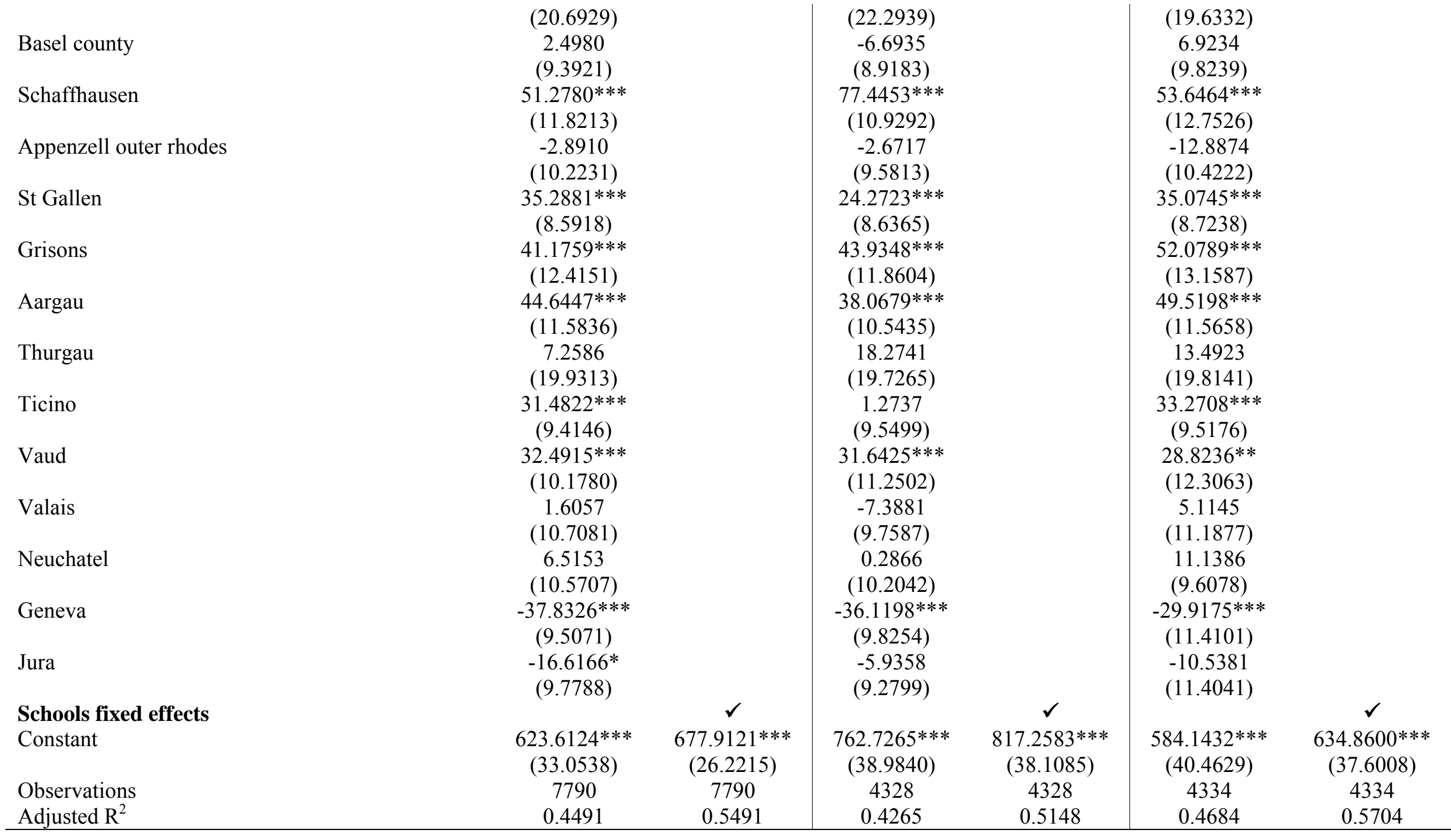

Source: PISA 2000 (national sample). Notes: dependant variables are test scores in reading literacy (columns 1 and 2), mathematics literacy (columns 3 and 4) and science literacy (columns 5 and 6). All observations are weighted with the students' weight. Clustered robust standard errors (at the school level) are in parentheses. *: significant at $10 \% ; *$ : significant at $5 \% ; * * *$ : significant at $1 \%$. 


\section{Table 9}

The impact of immigration status on reading, mathematics and science literacy + Interaction term (number of siblings x second-generation immigrant)

\begin{tabular}{|c|c|c|c|c|c|c|}
\hline \multirow[b]{2}{*}{ Swiss } & \multicolumn{2}{|c|}{ Reading } & \multicolumn{2}{|c|}{ Mathematics } & \multicolumn{2}{|c|}{ Science } \\
\hline & ref. & ref. & ref. & ref. & ref. & ref. \\
\hline Second-generation immigrant & $\begin{array}{c}-16.3409 * * \\
(6.8261)\end{array}$ & $\begin{array}{c}-18.0883 * * * \\
(6.4299)\end{array}$ & $\begin{array}{c}-19.7308 * * \\
(8.0010)\end{array}$ & $\begin{array}{c}-20.0607 * * \\
(8.4146)\end{array}$ & $\begin{array}{c}-19.0384 * * \\
(9.3711)\end{array}$ & $\begin{array}{c}-23.9288 * * * \\
(8.7841)\end{array}$ \\
\hline First-generation immigrant & $\begin{array}{c}-22.6272 * * * \\
(4.3911)\end{array}$ & $\begin{array}{c}-22.4475 * * * \\
(3.9752)\end{array}$ & $\begin{array}{c}-27.7794 * * * \\
(5.6324)\end{array}$ & $\begin{array}{c}-27.1832 * * * \\
(5.6087)\end{array}$ & $\begin{array}{c}-32.5833 * * * \\
(6.4956)\end{array}$ & $\begin{array}{c}-35.6697 * * * \\
(6.1620)\end{array}$ \\
\hline Age (in months) & $\begin{array}{c}-1.5294 * * * \\
(0.1434)\end{array}$ & $\begin{array}{c}-1.4238 * * * \\
(0.1281)\end{array}$ & $\begin{array}{c}-1.7903 * * * \\
(0.1824)\end{array}$ & $\begin{array}{c}-1.7527 * * * \\
(0.1893)\end{array}$ & $\begin{array}{c}-1.2332 * * * \\
(0.1701)\end{array}$ & $\begin{array}{c}-1.0497 * * * \\
(0.1708)\end{array}$ \\
\hline Age is missing & $\begin{array}{c}-274.3353 * * * \\
(38.9685)\end{array}$ & $\begin{array}{c}-249.2344 * * * \\
(33.9086)\end{array}$ & $\begin{array}{c}-356.1451 * * * \\
(49.1635)\end{array}$ & $\begin{array}{c}-332.8769 * * * \\
(48.6291)\end{array}$ & $\begin{array}{c}-224.3378^{* * *} \\
(45.6946)\end{array}$ & $\begin{array}{c}-189.8532 * * * \\
(43.4388)\end{array}$ \\
\hline Female & $\begin{array}{c}16.8466^{* * *} \\
(2.0050)\end{array}$ & $\begin{array}{c}16.4332 * * * \\
(1.9404)\end{array}$ & $\begin{array}{c}-29.3003 * * * \\
(2.7331)\end{array}$ & $\begin{array}{c}-29.8452 * * * \\
(2.6373)\end{array}$ & $\begin{array}{c}-17.4698 * * * \\
(2.5760)\end{array}$ & $\begin{array}{c}-18.3368 * * * \\
(2.4522)\end{array}$ \\
\hline Language at home is the language of the test & $\begin{array}{c}22.1049 * * * \\
(3.2052)\end{array}$ & $\begin{array}{c}20.6167 * * * \\
(3.1794)\end{array}$ & $\begin{array}{c}23.4482 * * * \\
\quad(4.4178)\end{array}$ & $\begin{array}{c}21.7195 * * * \\
(4.4444)\end{array}$ & $\begin{array}{c}20.7753 * * * \\
(4.5170)\end{array}$ & $\begin{array}{c}18.1981 * * * \\
(4.5321)\end{array}$ \\
\hline Language at home is missing & $\begin{array}{c}0.2997 \\
(7.0673)\end{array}$ & $\begin{array}{c}2.4340 \\
(6.2521)\end{array}$ & $\begin{array}{c}2.4847 \\
(8.5548)\end{array}$ & $\begin{array}{c}3.1806 \\
(8.7563)\end{array}$ & $\begin{array}{c}-8.0061 \\
(9.3304)\end{array}$ & $\begin{array}{l}-5.6032 \\
(8.6956)\end{array}$ \\
\hline Family structure is nuclear & $\begin{array}{c}8.4301 * * * \\
(2.5820)\end{array}$ & $\begin{array}{c}5.7364 * * \\
(2.4336)\end{array}$ & $\begin{array}{c}12.1324 * * * \\
(3.7000)\end{array}$ & $\begin{array}{l}9.6996 * * \\
(3.7798)\end{array}$ & $\begin{array}{c}12.9484 * * * \\
(3.2245)\end{array}$ & $\begin{array}{c}10.4431 * * * \\
(3.0326)\end{array}$ \\
\hline Family structure is missing & $\begin{array}{l}-23.0106 \\
(15.1465)\end{array}$ & $\begin{array}{l}-20.3351 \\
(12.4647)\end{array}$ & $\begin{array}{l}-13.7503 \\
(16.6102)\end{array}$ & $\begin{array}{l}-18.5088 \\
(14.1823)\end{array}$ & $\begin{array}{c}-6.2623 \\
(18.2301)\end{array}$ & $\begin{array}{c}-7.2018 \\
(22.9099)\end{array}$ \\
\hline Number of siblings & $\begin{array}{c}-6.4223 * * * \\
(1.0364)\end{array}$ & $\begin{array}{c}-5.2305 * * * \\
(0.8854)\end{array}$ & $\begin{array}{c}-3.1602 * * \\
(1.2821)\end{array}$ & $\begin{array}{l}-1.7338 \\
(1.2280)\end{array}$ & $\begin{array}{c}-2.9849 * * \\
(1.3445)\end{array}$ & $\begin{array}{l}-2.0617 * \\
(1.1577)\end{array}$ \\
\hline Number of siblings is missing & $\begin{array}{c}-9.5883 \\
(10.7647)\end{array}$ & $\begin{array}{r}-15.2859 \\
(9.4948)\end{array}$ & $\begin{array}{l}-13.2535 \\
(16.7252)\end{array}$ & $\begin{array}{l}-20.0129 \\
(15.6573)\end{array}$ & $\begin{array}{c}0.5830 \\
(17.9309)\end{array}$ & $\begin{array}{c}0.7393 \\
(15.6623)\end{array}$ \\
\hline $\begin{array}{l}\text { Second-generation*number of siblings } \\
\text { Mother education: None or primary }\end{array}$ & $\begin{array}{l}3.3299 \\
(3.4996) \\
\text { ref. }\end{array}$ & $\begin{array}{l}2.7557 \\
(3.3825) \\
\text { ref. }\end{array}$ & $\begin{array}{l}-1.1405 \\
(4.4854) \\
\text { ref. }\end{array}$ & $\begin{array}{l}-2.4562 \\
(4.6964) \\
\text { ref. }\end{array}$ & $\begin{array}{l}-1.5071 \\
(4.4873) \\
\text { ref. }\end{array}$ & $\begin{array}{l}-0.5653 \\
(4.2466) \\
\text { ref. }\end{array}$ \\
\hline Lower secondary & $\begin{array}{c}14.1224 * * * \\
(5.3584)\end{array}$ & $\begin{array}{l}8.2797 * \\
(4.9658)\end{array}$ & $\begin{array}{c}8.8456 \\
(7.2427)\end{array}$ & $\begin{array}{c}5.4969 \\
(7.6628)\end{array}$ & $\begin{array}{c}13.0124 * * \\
(5.8401)\end{array}$ & $\begin{array}{l}9.6229 * \\
(5.7045)\end{array}$ \\
\hline Vocational or prevocational upper-secondary & $\begin{array}{c}27.8006 * * * \\
(5.8660)\end{array}$ & $\begin{array}{c}20.1318 * * * \\
(5.3431)\end{array}$ & $\begin{array}{c}18.4917 * * * \\
(7.0747)\end{array}$ & $\begin{array}{l}14.2638 * \\
(7.2403)\end{array}$ & $\begin{array}{c}27.5613 * * * \\
(6.9481)\end{array}$ & $\begin{array}{c}22.7771 * * * \\
(6.6934)\end{array}$ \\
\hline Upper secondary & $31.4248 * * *$ & $21.0993 * * *$ & $28.1546 * * *$ & $22.3848 * * *$ & $35.1788 * * *$ & $28.2316^{* * *}$ \\
\hline
\end{tabular}


Education level of mother is missing

Father education: None or primary

Lower secondary

Vocational or prevocational upper-secondary

Upper secondary

Education level of father is missing

\section{ISEI}

ISEI is missing

\section{Number of books at home is $\mathbf{0 - 1 0}$}

Number of books at home is $11-50$

Number of books at home is $51-100$

Number of books at home is $101-250$

Number of books at home is $251-500$

Number of books at home is 501 or plus

Number of books at home is missing

\section{School size}

School size is missing

\section{School/teacher ratio}

\begin{tabular}{|c|c|c|c|c|c|}
\hline$(5.9611)$ & $(5.0490)$ & $(7.9722)$ & $(8.1698)$ & $(6.7624)$ & $(6.0799)$ \\
\hline 1.7418 & -0.4007 & 1.9315 & 7.1643 & 8.4637 & 9.0815 \\
\hline$(8.0550)$ & $(6.7806)$ & (10.2677) & (9.9182) & $(9.3142)$ & (7.7412) \\
\hline ref. & ref. & ref. & ref. & ref. & ref. \\
\hline-2.1720 & 0.1669 & -6.6637 & -4.7647 & -6.5466 & -5.8910 \\
\hline$(4.5547)$ & $(4.3305)$ & $(5.8404)$ & $(5.4846)$ & $(5.9662)$ & $(5.7102)$ \\
\hline $10.5147 * *$ & $10.2473 * *$ & 3.0424 & 1.9180 & 9.3216 & 6.9621 \\
\hline$(5.0056)$ & $(4.8059)$ & $(6.0486)$ & $(5.9605)$ & $(6.7258)$ & $(6.3370)$ \\
\hline 6.0252 & 6.0158 & 4.0757 & 2.4206 & 1.2553 & -0.1818 \\
\hline$(5.4987)$ & $(4.9792)$ & (7.4189) & $(7.0922)$ & (6.9829) & $(6.2853)$ \\
\hline-7.4157 & -2.6130 & -14.2819 & $-14.2856^{*}$ & -11.4895 & -8.3296 \\
\hline$(6.3374)$ & $(5.3765)$ & $(8.9105)$ & $(8.5315)$ & $(8.6257)$ & $(7.8521)$ \\
\hline $0.6569 * * *$ & $0.4215 * * *$ & $0.3429 * * *$ & $0.1492 *$ & $0.5268 * * *$ & $0.2645 * * *$ \\
\hline$(0.0690)$ & $(0.0628)$ & $(0.0923)$ & $(0.0882)$ & $(0.0818)$ & $(0.0748)$ \\
\hline-2.9753 & -3.4909 & -16.5350 & -15.4178 & -1.8740 & -1.7516 \\
\hline$(8.1667)$ & $(7.3650)$ & (10.7155) & (10.4395) & (10.6859) & $(9.5618)$ \\
\hline ref. & ref. & ref. & ref. & ref. & ref. \\
\hline $24.8053 * * *$ & $23.9269 * * *$ & $19.0917 * * *$ & $17.9598 * * *$ & $16.9328 * * *$ & $16.0633 * * *$ \\
\hline$(3.9484)$ & $(3.8100)$ & $(5.2756)$ & $(4.7410)$ & $(5.3428)$ & (5.3399) \\
\hline $33.0298 * * *$ & $28.7189 * * *$ & $21.8825 * * *$ & $20.2206 * * *$ & $29.6755 * * *$ & $24.2566 * * *$ \\
\hline$(4.2861)$ & (3.7513) & $(5.1695)$ & $(4.6416)$ & $(5.3920)$ & $(5.1960)$ \\
\hline $46.4314 * * *$ & $38.2403 * * *$ & $41.4540 * * *$ & $32.5234 * * *$ & $45.8111 * * *$ & $37.0122 * * *$ \\
\hline$(4.2073)$ & $(3.8685)$ & $(5.3884)$ & (4.8133) & $(5.4090)$ & (5.3896) \\
\hline $55.2126^{* * *}$ & $48.1738 * * *$ & $42.0937 * * *$ & $35.6347 * * *$ & $53.2391 * * *$ & $45.1070 * * *$ \\
\hline$(4.3731)$ & $(4.0206)$ & $(5.7231)$ & $(5.4265)$ & $(5.7345)$ & (5.8409) \\
\hline $55.0516^{* * *}$ & $47.0401 * * *$ & $47.7567 * * *$ & $39.8604 * * *$ & $58.2919 * * *$ & $48.3667 * * *$ \\
\hline$(4.7270)$ & $(4.4893)$ & $(5.6956)$ & $(5.2836)$ & $(6.8571)$ & $(6.9123)$ \\
\hline 3.1810 & -2.5933 & $22.5250 * *$ & $15.3046^{*}$ & -1.9942 & -10.8191 \\
\hline (11.3904) & $(9.4676)$ & (10.0300) & $(8.5331)$ & $(11.3716)$ & (10.8745) \\
\hline $0.0284 * * *$ & & $0.0273 * * *$ & & $0.0369 * * *$ & \\
\hline$(0.0098)$ & & $(0.0098)$ & & $(0.0108)$ & \\
\hline 10.5107 & & 16.9332 & & 13.4746 & \\
\hline$(23.6154)$ & & $(22.3113)$ & & (24.0389) & \\
\hline$-2.0962 * * *$ & & $-2.0504 * * *$ & & $-2.0767 * *$ & \\
\hline$(0.6826)$ & & $(0.5966)$ & & $(0.8190)$ & \\
\hline
\end{tabular}


School/teacher ratio is missing

$-56.9313 * *$

(23.3183)

Proportion of teachers ISCED 5

Proportion of teachers ISCED 5 is missing

\section{School location is in a village}

Small town

Town

City

School location is missing

\section{Zurich}

Bern

Lucerne

Schwyz

Obwalden

Nidwalden

Glarus

Zug

Fribourg

Solothurn

Basel city
$77.5575 * * *$

(8.9559)

$50.0923 * * *$

(10.5401)

ref.

$-0.5119$

(7.0093)

3.8163

(8.3782)

0.1014

(9.0605)

0.2707

(17.9638)

$$
\text { ref. }
$$

$23.4933 * * *$

(8.3112)

8.8695

(15.0638)

42.3817*

(22.8587)

$60.3507 * * *$

(18.1865)

$142.3767 * *$

(13.4180)

0.3663

(8.7464)

58.1460 **

(23.1714)

8.9045

(11.4696)

23.4840

(16.4212)

15.6967
$-57.0792 * * *$

(20.9580)

$77.9779 * * *$

(8.4815)

$48.8356 * * *$

(10.1219)

ref.

$-1.8257$

(6.8831)

0.6451

(8.3874)

$-2.1062$

9.5130)

$-16.7581$

(19.0709)

ref.

12.6829

(7.9686)

$-1.0344$

(14.7392)

29.9508*

(17.1863)

$60.9261 * * *$

(18.0270)

$129.8296 * * *$

(14.7330)

$-29.8116 * * *$

(8.5710)

46.1522**

(23.1254)

11.2216

(11.7583)

14.8584

(17.8438)

6.9995

$$
\begin{gathered}
-56.4889 * * \\
(24.5530) \\
83.0852 * * \\
(8.9784) \\
57.7323 * * * \\
(10.9792) \\
\text { ref. } \\
-1.3569 \\
(7.1817) \\
3.0304 \\
(8.9180) \\
-6.4005 \\
(10.0100) \\
-6.4404 \\
(21.3704) \\
\text { ref. } \\
21.5897 * * \\
(8.5592) \\
2.3869 \\
(16.3099) \\
43.6302 * \\
(22.2073) \\
54.2265 * * * \\
(17.1532) \\
130.7742 * * \\
(14.3307) \\
-2.6197 \\
(9.7321) \\
51.2850 * \\
(28.0027) \\
22.1334 * \\
(12.0078) \\
26.2435 \\
(18.1603) \\
25.3974 \\
\end{gathered}
$$




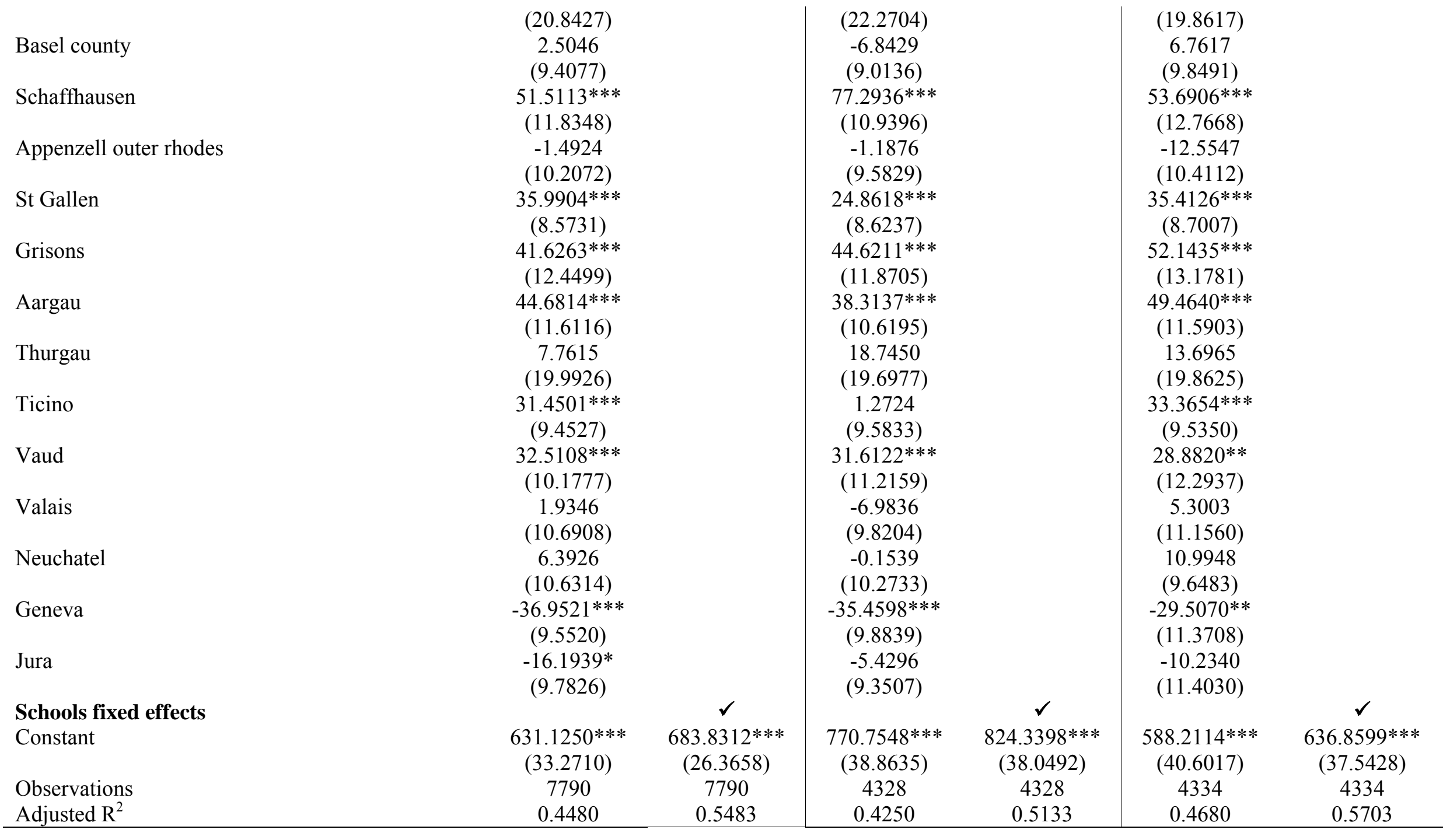

Source: PISA 2000 (national sample). Notes: dependant variables are test scores in reading literacy (columns 1 and 2), mathematics literacy (columns 3 and 4) and science literacy (columns 5 and 6). All observations are weighted with the students' weight. Clustered robust standard errors (at the school level) are in parentheses. *: significant at $10 \% ; *$ : significant at $5 \% ; * *$ : significant at $1 \%$. 


\section{Table 10}

The Juhn, Murphy and Pierce decomposition

\begin{tabular}{|c|c|c|c|c|}
\hline & \multirow{2}{*}{\multicolumn{4}{|c|}{ Swiss $(\mathrm{N}=6239)-$ Second-generation immigrant $(\mathrm{N}=720)$}} \\
\hline & & & & \\
\hline & Total score gap & $\begin{array}{l}\text { Characteristics } \\
\text { effect }\end{array}$ & Return effect & $\begin{array}{l}\text { Residual } \\
\text { effect }\end{array}$ \\
\hline $\begin{array}{l}\text { Mean } \\
(\%)\end{array}$ & $\begin{array}{l}54.2627 \\
(100)\end{array}$ & $\begin{array}{l}48.5782 \\
(89.52)\end{array}$ & $\begin{array}{l}5.2293 \\
(9.64)\end{array}$ & $\begin{array}{l}0.4552 \\
(0.84)\end{array}$ \\
\hline Percentile 5 & $\begin{array}{l}56.9980 \\
(100)\end{array}$ & $\begin{array}{l}51.5531 \\
(90.45)\end{array}$ & $\begin{array}{l}2.9715 \\
(5.21)\end{array}$ & $\begin{array}{l}2.4734 \\
(4.34)\end{array}$ \\
\hline Percentile 10 & $\begin{array}{l}61.0020 \\
(100)\end{array}$ & $\begin{array}{l}51.3701 \\
(84.21)\end{array}$ & $\begin{array}{l}5.3860 \\
(8.83)\end{array}$ & $\begin{array}{l}4.2460 \\
(6.96)\end{array}$ \\
\hline Percentile 25 & $\begin{array}{l}64.3560 \\
(100)\end{array}$ & $\begin{array}{l}57.8279 \\
(89.86)\end{array}$ & $\begin{array}{l}5.6315 \\
(8.75)\end{array}$ & $\begin{array}{l}0.8966 \\
(1.39)\end{array}$ \\
\hline Median (p50) & $\begin{array}{l}55.9660 \\
(100)\end{array}$ & $\begin{array}{l}52.4404 \\
(93.70)\end{array}$ & $\begin{array}{l}2.6380 \\
(4.71)\end{array}$ & $\begin{array}{l}0.8877 \\
(1.59)\end{array}$ \\
\hline Percentile 75 & $\begin{array}{l}39.9660 \\
(100)\end{array}$ & $\begin{array}{l}44.2155 \\
(110.63)\end{array}$ & $\begin{array}{l}-1.8810 \\
(-4.71)\end{array}$ & $\begin{array}{l}-2.3685 \\
(-5.93)\end{array}$ \\
\hline Percentile 90 & $\begin{array}{l}38.1120 \\
(100)\end{array}$ & $\begin{array}{l}35.6703 \\
(93.59)\end{array}$ & $\begin{array}{l}6.4375 \\
(16.89)\end{array}$ & $\begin{array}{l}-3.9958 \\
(-10.48)\end{array}$ \\
\hline \multirow[t]{3}{*}{ Percentile 95} & $\begin{array}{l}42.4380 \\
(100)\end{array}$ & $\begin{array}{l}39.9865 \\
(94.22)\end{array}$ & $\begin{array}{l}4.2827 \\
(10.09)\end{array}$ & $\begin{array}{l}-1.8312 \\
(-4.32)\end{array}$ \\
\hline & \multicolumn{4}{|c|}{ Swiss $(\mathrm{N}=6239)$ - First-generation immigrant $(\mathrm{N}=831)$} \\
\hline & Total score gap & $\begin{array}{l}\text { Characteristics } \\
\text { effect }\end{array}$ & Return effect & $\begin{array}{l}\text { Residual } \\
\text { effect }\end{array}$ \\
\hline $\begin{array}{l}\text { Mean } \\
(\%)\end{array}$ & $\begin{array}{l}94.0122 \\
(100)\end{array}$ & $\begin{array}{l}77.4988 \\
(82.43)\end{array}$ & $\begin{array}{l}16.1228 \\
(17.15)\end{array}$ & $\begin{array}{l}0.3905 \\
(0.42)\end{array}$ \\
\hline Percentile 5 & $\begin{array}{l}104.9380 \\
(100)\end{array}$ & $\begin{array}{l}69.5911 \\
(66.32)\end{array}$ & $\begin{array}{l}29.8238 \\
(28.42)\end{array}$ & $\begin{array}{l}5.5231 \\
(5.26)\end{array}$ \\
\hline Percentile 10 & $\begin{array}{l}105.5240 \\
(100)\end{array}$ & $\begin{array}{l}76.2718 \\
(72.28)\end{array}$ & $\begin{array}{l}28.1457 \\
(26.67)\end{array}$ & $\begin{array}{l}1.1065 \\
(1.05)\end{array}$ \\
\hline Percentile 25 & $\begin{array}{l}105.0778 \\
(100)\end{array}$ & $\begin{array}{l}86.6007 \\
(82.42)\end{array}$ & $\begin{array}{l}14.5392 \\
(13.84)\end{array}$ & $\begin{array}{l}3.9380 \\
(3.75)\end{array}$ \\
\hline Median (p50) & $\begin{array}{l}99.2340 \\
(100)\end{array}$ & $\begin{array}{l}85.7380 \\
(86.40)\end{array}$ & $\begin{array}{l}13.3152 \\
(13.42)\end{array}$ & $\begin{array}{l}0.1809 \\
(0.18)\end{array}$ \\
\hline Percentile 75 & $\begin{array}{l}83.9000 \\
(100)\end{array}$ & $\begin{array}{l}75.7861 \\
(90.33)\end{array}$ & $\begin{array}{l}10.6226 \\
(12.66)\end{array}$ & $\begin{array}{l}-2.5087 \\
(-2.99)\end{array}$ \\
\hline Percentile 90 & $\begin{array}{l}68.6500 \\
(100)\end{array}$ & $\begin{array}{l}57.8070 \\
(84.21)\end{array}$ & $\begin{array}{l}15.6226 \\
(22.76)\end{array}$ & $\begin{array}{l}-4.7796 \\
(-6.96)\end{array}$ \\
\hline Percentile 95 & $\begin{array}{l}66.3360 \\
(100)\end{array}$ & $\begin{array}{l}51.5479 \\
(77.71)\end{array}$ & $\begin{array}{l}16.9595 \\
(25.57)\end{array}$ & $\begin{array}{l}-2.1714 \\
(-3.27)\end{array}$ \\
\hline
\end{tabular}

Data Source: PISA 2000 (national sample). Notes: the reference estimates are Swiss in both tables. 
Cahiers de recherche du Centre de Recherche Appliquée en Gestion (CRAG) de la Haute Ecole de Gestion - Genève

(C) 2010

CRAG - Centre de Recherche Appliquée en Gestion

Haute école de gestion - Genève

Campus de Battelle, Bâtiment $\mathrm{F}$

7 , route de Drize - 1227 Carouge - Suisse

$\bowtie$ crag@hesge.ch

www.hesge.ch/heg/crag

(ग) +41223881818

县 +41223881740

Tous les cahiers de recherche de la HEG sur RERO DOC : http://doc.rero.ch/collection/HEGGE i.REPORT?ln=fr 